Центр Российских Исследований RRC Working Paper Series

No. 45

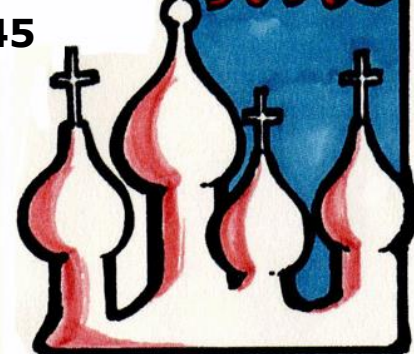

Radicalism versus Gradualism: An Analytical Survey of the Transition Strategy Debate Ichiro IWASAKI and Taku SUZUKI

April 2015: revised version July 2014: first version

RUSSIAN RESEARCH CENTER

THE INSTITUTE OF ECONOMIC RESEARCH

HITOTSUBASHI UNIVERSITY

Kunitachi, Tokyo, JAPAN 
RRC Working Paper No. 45

April 2015 [revised version; first published in July 2014]

\title{
Radicalism versus Gradualism* An Analytical Survey of the Transition Strategy Debate
}

\section{Ichiro Iwasaki ${ }^{\dagger}$ and Taku Suzuki ${ }^{\ddagger}$}

\begin{abstract}
Academic debate on a transition strategy for former socialist economies continues even a quarter century after the collapse of the communism in Central and Eastern Europe and the former Soviet Union. In this paper, through an analytical survey of 137 preceding studies, we present an overall picture of the debate and examine the relationship between the debate attitudes and the literature attributes in related studies. We found that the radicalists maintain a consistent debate attitude from the viewpoints of time speed and policy sequence of economic transition, while the debate attitude of the gradualists is more diversified. We also found that there is another group of researchers that stays within the framework of the radicalism-versus-gradualism debate while at the same time keeping at arm's length from both the radicalists and the gradualists. In addition, our cross tabulation analysis and regression estimation of qualitative selection models provide interesting findings on the relationship between the debate attitudes and the literature attributes.
\end{abstract}

JEL classification numbers: O20, O57, P20, P30, P52

Keywords: transition strategy debate, radicalism, gradualism, shock therapy, big-bang, analytical survey

\footnotetext{
${ }^{*}$ This research was financially supported by a Grant-in-Aid for scientific research from the Ministry of Education and Sciences in Japan (No. 23243032). We thank Robert M. Buckley, Maren Duvendack, Donald George, Yasushi Nakamura, and Tom D. Stanley as well as participants in the 54th National Congress of the Japanese Association for Comparative Economic Studies at Yamaguchi University, Yamaguchi, June 7-8, 2014, and the MAER-NET 2014 Colloquium at Athens University, Athens, September 11-13, 2014, for their helpful comments, suggestions, and insights. We also would like to thank Eriko Yoshida for her research assistance and Tammy Bicket for her editorial assitance. Needless to say, all remaining errors are solely our responsibility.

${ }^{\dagger}$ Institute of Economic Research, Hitotsubashi University, Naka 2-1, Kunitachi City, Tokyo 186-8603, Japan; Tel.: +81-42-580-8366; Fax: +81-42-580-8333; E-mail address: iiwasaki@ier.hit-u.ac.jp (corresponding author)

"Faculty of Economics, Teikyo University, Ohtsuka 359, Hachiouji City, 192-0395 Tokyo, Japan, Tel.: +81-42-678 -3455; E-mail address: pc01816@main.teikyo-u.ac.jp
} 


\section{Introduction}

If someone becomes excited when he or she hears the term transition strategy debate, that person is highly likely to have been engaged in policy practices or research activities related to the countries of Central and Eastern Europe (CEE) and the former Soviet Union (FSU) for at least the past quarter century. These countries renounced a socialist planned economy between the late 1980s and the early 1990s. The debate about what kind of reform track they should adopt toward the creation of a capitalist market economy, which is a more efficient economic system for pursuing further social welfare and economic growth, was so fierce at that time that policymakers and researchers who were involved in this debate have strong impressions that still return vividly from time to time.

While enjoying great relief and freedom in the wake of the end of the Cold War that had constrained the world for as long as 70 years, both the former socialist countries and the rest of the world immediately had to take their next step toward creating a new economic order. The transition strategy debate was about deciding the road map, and, hence, the argument on this subject involved many of leading economists and spread beyond the boundaries of the academic world. A dozen years later, "transition economics" was established as a major study area of modern economics, and the pioneering transition strategy debate has been one of the most important subjects in this research field. ${ }^{1}$

The transition strategy debate has developed as an argument between two conflicting reform philosophies, radicalism and gradualism. Here, radicalism denotes a policy philosophy that demands prompt and parallel implementations of the reform packages advocated by the Washington Consensus. ${ }^{2}$ It is also called shock therapy or the big-bang approach, reflecting the

1 In fact, Myant and Drahokoupil (2010), Turley and Luke (2010), and Åslund (2013), which represent recent basic textbooks of transition economics, devote many pages to discussing the transition strategy debate in their respective introductory chapters.

2 The Washington Consensus refers to a set of economic policy prescriptions formulated by a group of policymakers and researchers from Washington-based international institutions or administrative organizations such as the International Monetary Fund (IMF), the World Bank, and the US Treasury Department in the course of a series of economic crises that hit developing countries in the 1980s. According to Williamson (1990), the consensus basically consists of the following ten policy agendas: reduction of fiscal deficits, public expenditure priorities, tax reform, liberalization of interest rates, flexible foreign exchange rates, trade liberalization, promotion of foreign direct 
content of its relevant policy recommendations. On the other hand, gradualism is a collective term antithetical to radicalism; thus, the reform measures recommended by its advocates are extremely varied. Gradualists, however, show a certain congruity in their debate attitude toward a transition strategy, approving a milder policy implementation process in terms of time speed and/or emphasizing theoretical and practical needs to promote structural reforms in a reasonable policy sequence as compared to the radicalists.

As we will describe later, some researchers point out that, among transition economies, some nations have followed a unique reform track that cannot be categorized either as radicalism or as gradualism; some skeptics even question the raison d'etre of the transition strategy debate itself. However, they are in a minority, and it is indisputable that the overwhelming majority of people who have participated in the debate so far have stated their opinions, focusing on the validity and relevance of the two contrasting reform philosophies.

More than a quarter of a century has now passed since the fall of the Berlin Wall, an event symbolic of the demise of the Communist Bloc; the fever of that time has already become a memory of the past. However, despite Vladimir Popov's declaring "the end of the debate" (Popov, 2000a), academic discussion regarding transition strategies has continued, and there is no sign of convergence. It has been pointed out that one of the main reasons for the ongoing irreconcilable debate, in terms of ex-post economic performance, is that there are no obvious, definitive differences between countries that have promoted economic transition that follows radicalismbased policy guidance and countries that have carried out gradualism-based structural reforms. Notwithstanding, from the viewpoint of historical path dependency, the choice of a transition strategy still has significant influence on various levels and aspects of their national economies.

Therefore, it is still not the time to sum up the transition strategy debate. Nevertheless, it is possible to provide an overall picture of the debate based on studies accumulated during the past 26 years and to examine the relationship between the debate attitudes and literature attributes, such as authorship, research contents, and publication media. These efforts are meaningful research tasks for the sake of considering the future development of the debate. Therefore, in this

investment, privatization of state enterprises and other public assets, deregulation, and reinforcement of property rights. See Rodrik (2006) and Lütz and Kranke (2014) for their valuable comments and critiques on applying the Washington Consensus to CEE and FSU countries. 
paper, we will attempt to achieve these tasks through an analytical survey of 137 preceding studies that have contributed to the international debate on radicalism versus gradualism. In addition, we will try to unveil some issues to be tackled within the framework of the transition strategy debate by paying attention to the above-mentioned minority's views.

The results of our literature survey indicate that radicalists maintain a monolithic debate attitude, as a whole, while that of gradualists is more diversified. In fact, the latter can be divided into slow-paced gradualism, step-by-step gradualism, and eclectic gradualism groups, whose respective presences are almost balanced. Moreover, we also found that there is another group of researchers who stay within the radicalism-versus-gradualism debate framework while at the same time staying at arm's length from both the radicalists and the gradualists. In addition, our cross tabulation analysis and regression estimation of the qualitative selection models provide interesting findings regarding the relationship between the debate attitudes and the literature attributes in related studies.

The remainder of this paper is organized as follows: The next section will discuss the methodology of the literature search and an outline of the studies subject to our analytical survey. Section 3 will look at the overall structure of the transition strategy debate. Section 4 will review representative research works in the radicalism-versus-gradualism debate. Section 5 will examine the relationship between the debate attitudes and the literature attributes by means of statistical and econometrical methods. Finally, Section 6 will discuss a future agenda for paving the way toward a deeper debate beyond the traditional dichotomy, referring to heterodox views.

\section{Methodology of the Literature Search and Outline of the Studies Subject to Analytical survey}

As the first step in identifying relevant studies that argue for radicalism or gradualism as transition strategies from a planned system to a market economy during the period from 1989 to 2014, we searched EconLit, a representative electronic database of economic literature. ${ }^{3}$ We conducted this search using combinations of two keywords or terms including one of the following: big bang, gradualism, radicalism, shock therapy, and Washington Consensus, which are inseparable from

\footnotetext{
3 The final literature search was conducted in March of 2015.
} 
the transition strategy debate, as well as inflation, institution, liberalization, stabilization, and social costs, which also have deep connections with the debate from the viewpoint of transition policy. We used another keyword or phrase from among the following: transition economies, Central Europe, Eastern Europe, the former Soviet Union, China, or the respective names of each CEE and FSU country. Then, judging from the paper titles and abstracts, we excluded studies that were irrelevant to our issues and interests in this paper. As a result of this procedure, we found slightly more than 300 studies. In addition, we also collected studies (centering on books) that are widely regarded as having an important influence on the transition strategy debate, although they were not picked up from our mechanical search, and as many non-overlapping related research works as possible that were cited in the approximately 300 papers above. In this way, we collected a total of 378 studies.

Next, we further narrowed our focus to study works that can be subjected to our analytical survey by carefully reading the 378 studies one by one. As a result, we ultimately selected a total of 137 studies from Svejnar (1989) and Lipton and Sachs (1990), both pioneering works regarding transition strategies, to the latest publications, including Jakšić (2014) and Shleifer and Treisman (2014). Hereafter, we refer to a set of these 137 studies as the basic collection. ${ }^{4}$ Figure 1 shows the frequency distribution of the publication year of the 378 papers searched and the basic collection. As this figure shows, both are remarkably similar in terms of the composition by publication year. In fact, the correlation coefficient of the number of studies by publication year amounts to 0.757 . Figure 1 also indicates that the debate on transition strategy had become substantially active immediately after the breakdown of the Soviet Union in late 1991 and that it also had gathered remarkable momentum in 1994, five years after the fall of the Berlin Wall; in 1996, five years after the downfall of the Soviet Union; in 2000, the end of the century; and in the two years between 2009 and 2010, which marked the 20th anniversary of the demise of the Communist Bloc. This suggests that the transition strategy debate was strongly inspired by the exit of the Soviet Union from the world history and that transition researchers have continually revived their interest in this issue at each historical milestone.

Figure 2 shows the outline of the basic collection in terms of authorship, research content, and

\footnotetext{
${ }^{4}$ The complete list of the basic collection is provided in Appendix A.
} 
publication media. According to Panel (a) of this figure, the 137 studies in the basic collection were written by 196 authors on a gross basis, of which an overwhelmingly majority (160 authors) are researchers who belong to universities or other academic research institutions. Meanwhile, 16 authors, accounting for $8.2 \%$ of the total number, have been involved in the transition strategy debate, working at the IMF or the World Bank, both of which had strong and direct influences on policy decisions in the transition countries. Following them, the third largest group is comprised of 11 staff members at think tanks. Geographically, 152 authors (77.6\% of the total) are based in North America or Western Europe, while only 29 authors (14.8\% of the total) belong to institutions located in the CEE and FSU states. This fact proves that the international debate on transition strategies has been led by observers outside of the transition countries rather than by researchers in the very countries that have been carrying out the reforms.

In addition to affiliated institutions and their locations, we also investigated each author's research experience, gender, and assertiveness toward academic society, which may be related to the debate attitude. ${ }^{5}$ As Panel (a) of Figure 2 shows, the literature composition, in terms of the median of author's first publication year, ${ }^{6}$ reveals that papers written by the generation that started their research careers in the era when socialism existed in the CEE and FSU region and papers presented by the post-socialism generation almost perfectly counterbalance each other, with the rate being 69: 68 in this order. The largest bloc is comprised of authors who made their debut in the 1990s, producing 35.8\% (49 studies) of the basic collection. Moreover, studies written at least partly by a female researcher accounted for $12.4 \%$ (17 studies) of the total, while those written at least partly by either a world-famous or a very influential economist in the field of transition economics accounted for $20.4 \%$ (28 studies) of the total.

Panel (b) of Figure 2 shows the literature's composition on the basis of their research content. As shown in this panel, most of the literature that shapes the transition strategy debate neither focused on any particular region or country as the subject of their study nor limited their debate

5 The attention to gender arises from our experimental intuition that there may be a difference between genders in the degree of relative priority given to social stability as a criterion for policy judgments.

${ }^{6}$ We obtained information concerning the author's first publication year from the ProQuest database (http://www.proquest.com/), which extensively covers researchers worldwide. Taking co-authored papers into account, we used the median value as the proxy for the research experience. 
to any particular policy areas. The same panel also gives evidence that only $10.9 \%$ (15 studies) of the basic collection were published as research outcomes from academic projects. We can further confirm that literature proving their own assertions about ideal or desirable modes of transition strategy by means of mathematical economic models accounts for $16.8 \%$ (23 studies), and literature justifying their own assertions quantitatively by either conducting econometric analyses or using quantitative data (mostly official statistics) accounts for 33.6\% (46 studies).

The attributes of the basic collection, in terms of publication media, are shown in Panel (c) of Figure 2. This panel reveals that most studies in the basic collection were published as economic journal articles. In fact, 123 studies (89.8\%) of the entire collection are journal articles, and 108 studies (78.8\%) have been published in journals specializing in economics. ${ }^{7}$ Moreover, looking at the publication year of the 137 studies in five-year intervals, we found that, by and large, these studies are evenly distributed over the entire period, although there were slightly fewer studies published from 1989-1993 and slightly more studies published from 1999-2003. In addition to these attributes, we set 10 grading criteria for evaluating the quality level of the publication media. More specifically, in the case of journal articles, the criteria are based on journal rankings and the impact factor, while in the case of academic books and book chapters, the criteria are based on the presence of a peer-review system and literature information, such as the publishers. ${ }^{8}$ According to our evaluation, the quality level of the publication media has a negative correlation with the number of studies. Nevertheless, the number of studies published either in top-ranking journals (the 9-10th grade) or in the next-highest journals (the 6-8th grade) is not small. Actually, such studies account for $36.5 \%$ (50 studies) of the basic collection. ${ }^{9}$ This fact may reflect that the transition strategy debate, which has involved even a great number of world-famous researchers, was regarded as a critically important research subject for the entire economics society, which has been undergoing a big paradigm shift inspired by the end of socialism.

7 These high numbers are more likely to have resulted from our methodology of using EconLit as a prime means for the literature search and, hence, the above observation does not necessarily mean that economic journals are the main battlefield for the transition strategy debate.

${ }^{8}$ For more details on the method of evaluating the quality level, see Appendix B.

9 According to the journal ranking that we utilized to evaluate of the quality level of the publication media, the proportion of the 6-10th grade journals accounts for $26.0 \%$ (304 out of all 1,171 ranked journals). 


\section{Overall Structure of the Transition Strategy Debate}

In general, the opposing axis of academic debates among different schools or research groups with different stances gradually becomes more apparent as their arguments deepen or as time goes on. This also holds true for the quarter-century-old transition strategy debate. In fact, the initial debate, in which the pros and cons of radicalism and gradualism were discussed to determine which was a more appropriate transition strategy for former socialist countries, was not necessarily focused; the debate even seemed confused. However, when we look at the flow of the debate during the past 26 years from the present position, we can see clear boundaries between the debate attitudes in the relevant literature, although that is, of course, the benefit of hindsight. In our view, the most fundamental criteria are comprised of the following three perspectives: time speed, policy sequence, and institution. By checking each of 137 studies in the basic collection against these three criteria, we identified authors' willingness to accept or reject radicalism and their grounds for objection; subsequently, we created a bold classification of the preceding studies. ${ }^{10}$ In this section, we present the overall structure of the transition strategy debate emerging from this classification work.

With regard to radicalism advocates, including Lipton and Sachs (1990), Balcerowicz (1994), and others, their debate attitude is remarkably consistent in light of time speed and policy sequence. Indeed, the radicalists share an idea that big-bang and speedy implementations of policy packages are indispensable for establishing a market economy in the former socialist economies. The underlying logic of this idea is that economic transitions must be carried forward as quickly as possible and, consequently, a single round of expeditious execution of necessary reform measures is essential. In terms of the reasoning about why the transition to a market economy should be achieved speedily, radicalists underline the following three points: (a) strong demand from the international community, calling for the deterrence of backsliding into the Cold War period; (b) survival strategy for reformers who face off against pro-communist opposing forces;

\footnotetext{
${ }^{10}$ Based on the evaluation criteria described below, we performed this classification work in as objective a manner as possible. However, it is hard to say that our arbitrariness has been completely eliminated. In addition, the classification result does not necessarily correspond to the individual belief and/or stance of each author in the basic collection at the time of his or her writing.
} 
and (c) the necessity of cultivating a middle class that will proactively support democracy and a market economy. In other words, the radicalists tend to stress political reasoning to justify their debate attitude toward a transition strategy (Åslund, 2007; Turley and Luke, 2010).

Despite the consistency of its policy recommendations, however, the radicalists can be divided into two research groups. One is the universal radicalism group, represented by Murphy et al. (1992), de Melo et al. (1996), and Åslund (2007; 2009), which maintains that the best option for the CEE and FSU countries should be radicalism, irrespective of differences in the degree of perfection in the planned system and other historical preconditions. The second is the conditional radicalism group, including Klaus (1993) and others, which affirms that implementing a transition strategy based on radicalism is a better option than gradualism as long as a series of initial conditions antecedent to reforms, such as the government's adequate policy capability and the citizens' sufficient understanding and tolerance of capitalism, is minimally met. ${ }^{11}$ We note, however, that the latter group is clearly a minority, as compared to the former.

Meanwhile, gradualism advocates have a unified voice against the radicalists in criticizing radicalism's "speed-before-quality," "haphazard," and "unrealistic" approach. Moreover, gradualists contend that radicalism is highly likely to be associated with socially intolerable negative side effects. When it comes to basic reasons for justifying the gradualist approach, however, gradualists have a more varied rationale in comparison with their radicalist counterparts. Nevertheless, it is possible to classify the gradualists into several research groups, based upon which time speed and policy sequence are emphasized more in their debate attitude.

In this way, we come up with the first research group among the gradualists, which can be called the slow-paced gradualism group, including Etzioni (1992), Murrell (1992a; 1992b), Blanchard and Kremer (1997), and King (2002). This group asserts that the transition to a market economy should be carried forward over time so that any social downfall can be avoided, in light of the necessity of effectively controlling the side effects of structural reforms, such as political and social unrest, transformational recession (Kornai, 1994), unfair distribution of wealth, and

11 Although their conclusion or policy recommendation is different from that of "conditional radicalism," more than a few researchers emphasize the effect of the initial conditions on the transition process. For the latest studies, see BenYishay and Grosjean (2014) and Grosfeld and Zhravskaya (2015). 
increases in unemployment and poverty, as well as in light of the lawmaking and administrative capabilities of governments in transition economies, their security-enforcement power, and the limited capacity of citizens to adapt to large-scale social changes. In this regard, we point out that the slow-paced gradualism group does not necessarily express a strong objection to radicalism, with regard to an all-out and simultaneous undertaking of reform measures for economic transition.

In contrast to the debate attitude of the slow-paced gradualism group, some researchers particularly emphasize the importance of policy sequence in order to successfully carry out structural reforms that might drastically change a given economic system, while at the same time avoiding excessive social confusion. We call them the step-by-step gradualism group. Van Brabant (1993; 1994a; 1994b), Lian and Wei (1998), and Calcagno et al. (2006) represent this group. In addition to these step-by-step transition strategy advocates, the gradualists also embrace the institutional gradualism group, consisting of Hecht (1994), Liew (1995), Popov (2000a; 2000 b; 2007; 2009; 2012), and many others, who stress that the establishment of institutions that constitute the foundation of the market economy and democracy, such as property rights and the rule of law, should become the top priority in order to advance the transformation from the planned system to a market economy. They also argue that the upgrading of institutions is a basic precondition for carrying out marketization policies, including price liberalization and enterprise privatization, and thus, it should precede these policies. Therefore, the basic standpoint of the institutional gradualism group is not essentially different from that of the step-by-step gradualism group in the sense that both groups emphasize policy sequence for carrying out economic transition. ${ }^{12}$ For this reason, we include the institutional gradualism group in the step-by-step gradualism group in the broad sense.

Moreover, the gradualists comprise another mass of researchers who regard the assertions of both the slow-paced and the step-by-step gradualism groups as equally important justification for denouncing radicalism. Quite a few famous scholars, such as Dewatripont and Roland (1992a;

\footnotetext{
${ }^{12}$ It is noteworthy that the argument of the institutional gradualism group has something in common with a series of articles by Daron Acemoglu and others that insists upon the importance of institutions as a crucial determinant of the rise and fall of the state (Acemoglu et al., 2008; Acemoglu et al., 2011; Acemoglu and Robinson, 2012).
} 
1992b; 1995), Aghion and Blanchard (1994), North (1994), Stiglitz (1999), and Arrow (2000), belong to this group. We call them the eclectic gradualism group.

Further, there is another research group, including McMillan and Naughton (1992), Islam (1993), Fan (1994), and Papapanagos and Sanfey (2003), that takes the side of neither the radicalists nor the gradualists. The essence of their argument is that radicalism and gradualism are not intrinsically paradoxical to each other, but rather are mutually alternative options; therefore, neither of the two can always be superior to the other theoretically and practically. Based on this notion, they further maintain that, in the real world, policymakers may well choose either gradualism or radicalism as their basic transition strategy on a case-by-case basis, depending on the relevant country's actual conditions; in some cases, a mixture of both or switching between the two at different stages would be even possible. Their debate attitude can be described as neutralism because they remain in the framework of the radicalism-versus-gradualism debate while, at the same time, keeping at arm's length from both the radicalists and the gradualists. Neutralists have something in common with the conditional radicalism group; however, they should be clearly distinguished in the sense that their debate stance is more thoroughly neutral than is that of conditional radicalism.

As mentioned in the Introduction, all researchers who have discussed transition strategy by no means stay within the radicalism-versus-gradualism framework. For instance, Pomfret (2000), Herrmann-Pillath (2006), and some other researchers have claimed that some transition countries have carried out a "third" reform track, which cannot be classified as either radicalism or gradualism. Moreover, researchers such as Hoen (1996; 2010), Swaan and Lissowska (1996), and Liodakis (2001) have serious doubts about the significance of the transition strategy debate itself. These research groups can be respectively called third-way thinkers and transcendentalists. These two groups almost complete our categorization of researchers who have been deeply involved in the transition strategy debate. As for the heterodox research groups that keep a certain distance from the orthodox transition strategy debate, we will cover them in the concluding section of this paper.

Summing up the preceding discussion, we have illustrated in Figure 3 the overall structure of the transition strategy debate during the 26 years after the demise of the Communist Bloc in the CEE and FSU region. In accordance with this figure, we classified the 137 studies of the basic 
collection based on their respective debate attitudes. Figure 4 summarizes the results. As shown in Panel (a) of this figure, the gradualists leave both the radicalists and the neutralists far behind in terms of the number of their publications. In fact, 95 research works are classified as gradualism-advocating literature, accounting for $69.3 \%$ of the entire basic collection. In this sense, gradualism is the majority view. ${ }^{13}$

Meanwhile, 29 studies belong to the radicalists, accounting for $21.2 \%$ of the total. As Panel (b) of Figure 4 shows, 26 of these 29 studies were written by researchers who firmly believe in the universality of radicalism. This fact reflects the monolithic nature of the radicalists. The remaining 13 studies are products of researchers who expressed their neutral position in the debate; however, the neutralists do not achieve even half the number of studies by radicalists. In this way, the conflict between the radicalists and the gradualists is obvious.

Panel (c) of Figure 4 exhibits the subclassifications of the gradualists. According to this panel, the slow-paced gradualism group published 41 out of the 95 studies, or $43.2 \%$ of the total studies created by the gradualists. Meanwhile, the step-by-step gradualism group and the eclectic gradualism group published 33 studies (34.7\% of the total) and 21 studies (22.1\%), respectively, suggesting that the power balance is almost even among these three research groups. Moreover, 18 studies belong to the institutional gradualism group, which places the most emphasis on the importance of institution building, accounting for more than half (54.5\%) of the total studies from the step-by-step gradualism group.

This demonstrates that the debate attitude of the gradualists is varied, and no particular view overwhelms the others. This is in clear contrast to the radicalists, who demonstrate a consistent view about their policy recommendation for economic transition.

\section{Overview of the Radicalism-versus-Gradualism Debate}

In this section, we will outline the main arguments in the radicalism-versus-gradualism debate. First, we review representative research works of the radicalists. Then we will deal with those of

\footnotetext{
${ }^{13}$ Without duplication, the number of all authors in the basic collection is 157 . Among them are 153 authors whose articles are all classified in a single category; these include 36 radicalists $(23.5 \%)$, 19 neutralists (12.4\%), and 98 gradualists (64.1\%). Therefore, we can also confirm the predominance of gradualists based on the number of authors in each category.
} 
the gradualists and the neutralists one after the other.

\subsection{Radicalism}

As described in Section 3, research works presented by the universal radicalism group, which strongly advocates the superiority of radicalism over other options, account for most of the studies produced by radicalists. Accordingly, we first touch on the debate attitude of this research group and then move on to the conditional radicalism group.

\subsubsection{Universal Radicalism}

Many early studies of the universal radicalism group emphasized the time speed, taking reform experiences within socialism in the CEE countries into account; their momentum had a great influence on the subsequent research trends. For example, just after the fall of the Berlin Wall, Lipton and Sachs (1990) initiated the debate on transition strategy and took a leading role among the Western radicalists, arguing that speed itself is the most important reform element in economic transition. Murphy et al. (1992) also advocated for the speedy and all-out implementation of reform measures, arguing that partial reforms (gradualism-based transition strategy) would easily destroy an existing economic system; however, they can hardly accomplish an efficient market and, as a result, they might cause a substantial decrease in production. Almost at the same time, Brada (1993) stated that rapid reforms would benefit post-communist countries and that the claim of gradualists is not only inappropriate, in light of history and reality in the CEE countries, but also inconsistent with democracy. Moreover, Balcerowicz and Gelb (1995) discussed that radicalism-based liberalization policies and macroeconomic stabilization measures would involve the lowest risk and would not prevent reforms and production, even in the medium-term prospect.

Thereafter, the universal radicalism group has shown a stronger tendency to support and justify the speedy big-bang approach in a more proactive manner, referring to the actual transition processes in the CEE and FSU countries and their ex-post economic performances. For example, Lavigne (2000) endorsed radicalism as a proper reform track based on her retrospection on reform achievements during the 1990s. Andres Åslund (2007), who acknowledges that he is a promoter of radicalism, refuted criticism from gradualists by claiming that failures in transition countries, especially economic turmoil in Russia, were caused not by the radicalism-based reforms themselves but by the lukewarm implementation of necessary reform measures by the transition 
governments. Two years later, he also asserted that although Russia might have failed in politics, it had achieved a certain success in its economic transition, suggesting that the source of success in the Russian structural reforms should be attributed to shock therapy (Åslund, 2009).

As reported in Section 2, the number of studies that performed empirical analysis is very limited, and most of them belong to the universal radicalism group. Sachs (1996) is one of pioneering works in this research field. Using a cross-sectional dataset of 25 transition economies in 1995, Sachs found a positive correlation between progress in liberalization and economic growth and, consequently, made a conclusion in favor of radicalism. Moreover, de Melo et al. (1996; 2001) gave countenance to radicalism by verifying a positive correlation between the speed of liberalization and economic growth using macroeconomic data of 28 transition economies for the first half of the 1990s. Selowsky and Martin (1997) and Berg et al. (1999) also demonstrated their own support for radicalism, presenting empirical evidence similar to that of Sachs (1996) and de Melo et al. $(1996 ; 2001)$.

\subsubsection{Conditional Radicalism}

Some radicalists express some hesitations regarding the rapid and all-out execution of reform measures to advance the economic transition to a market economy, although they are extremely minor. For example, Klaus (1993) wrote that radicalism can be constantly recommended only if institutions and other environments are consistent with policies. Balcerowicz (1994) also stated that, as long as minimum conditions for carrying out radicalism-based transition strategies are satisfied, radicalism should precede all alternative approaches in order to ensure the irreversibility of reforms. ${ }^{14}$ The conditional radicalism group keeps their debate attitude essentially the same as that of the universal radicalism group in the sense that they consider radicalism to be a reform philosophy superior to gradualism. Nevertheless, it is also true that there is an obvious enthusiasm gap between the groups.

\subsection{Gradualism}

${ }^{14}$ There are some cases, such as Balcerowicz (1994) and Balcerowicz and Gelb (1995), where the same author belongs to different research groups at the same time, reflecting the presence of coauthors or different timing of publications, etc., although such cases are extremely limited. In this regard, however, we have not found any single case where the same author belongs to two groups in which the debate attitudes are extremely different from each other. 
As discussed in Section 3, gradualists are divided into the following three research groups in accordance with their respective logic lines for criticizing radicalism: the slow-paced gradualism group, the step-by-step gradualism group, including the institutional gradualism group, and the eclectic gradualism group. In the following subsections, we will look at the debate content of these three groups in turn.

\subsubsection{Slow-Paced Gradualism}

Arguments of the slow-paced gradualism group mirror those of the universal radicalism group. This means that, in the early stage of the debate, this group tried to justify gradualism based on economic theories and, as economic transition progressed in the former Communist Bloc, it began to support gradualism, referring to the reality of structural reforms and/or socioeconomic situations in the CEE and FSU countries or China.

Peter Murrell (1992a; 1992b) manifested a view representative of slow-paced gradualism at the very beginning of the debate. For example, in Murrell (1992a), he pointed out that drastic reforms of state-owned enterprises have a great risk of interfering with private entrepreneurship; thus, he advocated for slow-paced implementation of enterprise reforms. Meanwhile, in Murrell (1992b), he argued that most successful reform experiments in CEE are rooted in small-scale accumulated institutional changes over time; therefore, he strongly recommended slow-paced structural reforms. In the same period, Etzioni (1992) also maintained that social changes are intrinsically incremental and, thus, impossible to accelerate by any means; accordingly, he argued that the transition strategy itself should also be gradual. During the 1990s, numerous papers that share the debate attitude of Etzioni (1992) were published, such as Bhagwati (1994), Gel'vanovskii (1994), Dehejia (1996), and many others.

Afterward, as is the case with the universal radicalism group, the slow-paced gradualism group has increasingly leaned on ex-post reform achievements or economic performances in transition countries as supporting facts for gradualism. Above all, the remarkable successes of China and the tragic failures of Russia have frequently been cited by this group to enforce their assertions. A good example is Blanchard and Kremer (1997). In this well-known paper, they argued that, in the case of China, in addition to the low degree of industrialization, maintenance of the Communist Party's political power, and the decentralized development system, its gradual and 
slow-paced economic reforms were significantly effective to avoid what they called disorganization. Comparing Russia with Poland, where the privatization policy had been postponed until promising investors appeared, King (2002) expressed criticism of radicalism by stating that, in Russia, fast and sloppy enterprise privatization caused serious damage to company management, which in turn deepened the economic crisis in this country. Many of studies that expressed a debate attitude similar to that of Blanchard and Kremer (1997) and King (2002) appeared in the 2000s, including Rosefielde (2001), Molchanov (2005), Zweynert (2006), and Rozzelle and Swinnen (2009).

As demonstrated above, discussions by the slow-paced gradualism group were remarkably active. However, the number of studies that empirically verified their arguments is extremely limited. Sušjan and Redek (2008) is a valuable study from this viewpoint. Using panel data of 23 transition economies for the period of 1995-2002, they found that transition-specific uncertainty caused by radicalism-based high-speed reforms is highly likely to disturb economic growth in these countries. Thus, their empirical results are regarded to serve as good reasons for the slowpaced transition strategy.

\subsubsection{Step-by-Step and Institutional Gradualism}

Together with discussions related to slow-paced gradualism, those regarding step-by-step gradualism were also very active from the beginning of the debate. Jozef Van Brabant provided a series of pioneering studies to support the step-wise transition strategy in the early 1990s (Van Brabant, 1993; 1994a; 1994b). In these works, he consistently stressed the importance of policy sequence, although he did not completely rule out rapid reforms. Actually, he wrote that the stabilization policy is the very first one to be implemented among marketization measures, and, on the other hand, trade liberalization and disposal of non-performing loans should be dealt with in a careful manner based on a reasonable policy sequence. Lian and Wei (1998) also argued that partial reforms are more desirable than the big-bang approach; hence, gradualism, which represents a series of partial reforms, is a superior transition strategy to radicalism. Following these works, several country studies that give positive evaluation to the step-by-step approach were published one after the other. For instance, Calcagno et al. (2006), which investigated the steel industry in Romania, pointed out that the massive restructuring of state-owned companies 
that had been implemented almost in parallel with enterprise privatization subsequently caused serious problems in this country. Minniti and Polutnik (2007) highly evaluated the Slovenian stepby-step reforms based on their study of the country's currency conversion process and antiinflation policies.

Meanwhile, Hecht (1994) presented a groundbreaking study advocating institutional gradualism. In this paper, he stated that structural reforms in the former socialist countries should focus more on the establishment of property rights and the rule of law; then, from this viewpoint, he sharply criticized radicalism, which downplays the role of institutions. Dealing with Chinese experiences, Liew (1995) also emphasized that ensuring sound institutions, including a strong central state, is essential for promoting reforms. Furthermore, Noman (1999) stressed that strong institutions are more important than anything else to avoid or mitigate the adverse effects of economic liberalization, including income disparity and capital flight. In addition, Coyne and Boettke (2006) pointed out that keeping the consistency among different institutions is more essential than adjusting the reform speed for successful economic transition. As demonstrated in these works, researchers who belong to the institutional gradualism group presented a series of discussions that placed emphasis on the priority of institution building over other reform measures.

It is Vladimir Popov who intensely and tirelessly advocated the institutionalist approach through his numerous studies. As one of the leading figures in the transition strategy debate, he repeatedly claimed the importance of institutions in the systemic transformation process toward a market economy. In fact, in Popov (2000b), he pointed out that $90 \%$ of the failures in transition economies are attributable to grave blunders in maintaining strong institutions, not to the liberalization policies themselves. Nine years later, he also stated that the creation and maintenance of powerful institutions is the most essential part for the sake of economic growth in transition countries (Popov, 2009). At the same time, he presented supporting evidence for the institutionalist approach in several empirical studies (Popov, 2000a; 2007; 2012). As mentioned in Section 2, the international debate has been and still is led mainly by American and Western European researchers. Among them, Vladimir Popov is playing a great role as one of the strong promoters of institutional gradualism from the Russian viewpoint. ${ }^{15}$

\footnotetext{
${ }^{15}$ In this regard, however, he is mainly based at the Institute of European, Russian, and Eurasian Studies at Carleton University in Ottawa as well as the United Nations.
} 


\subsubsection{Eclectic Gradualism}

More than a few researchers place emphasis on both time speed and policy sequence as reasoning for gradualism. From this point of view, Dewatripont and Roland (1992a; 1992b; 1995) are representative studies during the early stage of the debate. In the two papers published in 1992, they asserted that gradual reforms with a careful and step-by-step approach would be the most appropriate strategy, taking the fiscal cost of structural reforms into account. Three years later, they also stated that slow-paced and step-by-step reform measures not only are easier to implement but also get returns from investment faster than a rapid and all-out marketization, on the condition that the relevant policy sequence must get public support. Almost in the same period, Aghion and Blanchard (1994) made policy recommendations that take account of both time speed and policy sequence for arranging the transition strategy in the proper way, arguing that it is difficult and undesirable to accelerate economic transition and that creating employment should be the first priority among various reform measures.

The eclectic gradualism group is characterized by the outstanding presence of Nobel laureates. Indeed, the slow-paced and step-by-step transition strategies are strongly encouraged by Douglass C. North, a prominent scholar in the new institutional economics, Joseph E. Stiglitz, who paved the way for the economics of asymmetric information, and Kenneth J. Arrow, a leading figure in social choice theory. More specifically, North (1994) advocated for the slow-paced and step-bystep reform approaches from his insights into the role of informal institutions (norms) in economic systems and the long-term nature of institutional changes. From the viewpoint of bounded rationality, Stiglitz (1999) severely criticized the unreality of the neoclassical model that many radicalists rely upon, while Arrow (2000) directed our attention to the difficulty of citizens in the former socialist countries to perceive and understand newly introduced price and market mechanisms. The involvement of these world-famous economists in the transition strategy debate greatly influenced both the direction of the debate and the power balance among research groups.

Together with literature by the aforementioned Nobel Prize winners, a series of research works by John Marangos also made noteworthy contributions to the eclectic gradualism group (Marangos, 2003; 2004a; 2004b; 2006). In these papers, he consistently touched on the importance of time speed, and his emphasis on policy sequence has also been increasing in 
proportion to the development of his research. In recent years, he not only advocated for gradualism but also argued that former socialist countries should aim for a post-Keynesian and market socialism economic system.

\subsection{Neutralism}

Finally, we will briefly describe the main perspectives of the neutralists. As with the gradualists, the naturalists also published more than a few papers that lean on reform achievements and/or economic performances of China. McMillan and Naughton (1992) is one such study that delivered a unique policy perspective, which depends neither on radicalism nor gradualism. More specifically, describing the many problems of China's reform and open-door policies, although these reform measures were successful in various aspects, they concluded that China's experiences neither deny the radicalism-based transition strategy nor justify the gradualist approach. Moreover, Islam (1993) showed his neutral stance, that radicalism and gradualism are both feasible options, stating that reform speed should be considered in light of different time spans for policy effects to emerge in each economic field; this is true for policy sequence, also.

Neutralists also published several works that emphasize the essential nature of strategic flexibility for successful promotion of the economic transition. For example, according to Fun (1994), both radicalism and gradualism can serve as the more appropriate solution, subject to given conditions in a transition economy. Furthermore, some studies proposed that transition countries should switch their reform modes flexibly with passing time. A typical example is Papapanagos and Sanfey (2003). In this paper, developing a unique mathematical model, they asserted that labor reallocation is better implemented in a gradual manner in the early stage of transition, but a rapid restructuring of the labor market is more desirable in the long-run; consequently, mode switching is required for successful transition. Despite their minor presence, neutralists provide a bridge between radicalists and gradualists and, by playing such a role, present meaningful opinions toward a constructive convergence in the transition strategy debate.

\section{Relationship between Debate Attitude and Literature Attributes}

Through the previous discussions, we have revealed the overall picture of the literature attributes and the debate attitudes of the basic collection. As a next step, we will examine the relationship 
between these two elements by means of statistical and econometric methods. First, we will conduct a cross tabulation analysis to test the independence of the literature attributes from the debate attitudes. Then, we will estimate qualitative choice models to regress the debate attitudes toward a series of the literature attributes simultaneously.

Table 1 shows the cross tables. In reference to the overall structure of the transition strategy debate described in Section 3, the columns of this table feature not only the three main categories of debate attitudes, consisting of radicalism, neutralism, and gradualism, but also five subcategories, comprised of the two radicalist groups and the three gradualist groups. Meanwhile, the table rows contain all 14 kinds of literature attributes mentioned in Section 2. Unlike Figure 2, however, this table provides a more-detailed breakdown of subject regions and subject policy areas. We test the interdependence of the debate attitudes and the literature attributes based on the three main categories (Test I) and the five subcategories plus neutralism (Test II), separately. Table 1 reports the results of the chi-square test of independence as well as Cramér's coefficient of association. ${ }^{16}$

According to the test results, the null hypothesis that the debate attitudes and a given literature attribute are independent is rejected at the $10 \%$ or less significance level, both in the cases of Test I and II in relation to the six attributes including: (1) author's affiliation, (2) location, (3) median value of first publication year, (4) intensity of empirical examination, (5) type of publication media, and (6) its quality level. In addition, in the case of subject policy areas and specialized fields of publication media, the null hypothesis is rejected in Test II. These results indicate that the differences in debate attitudes are statistically associated with many of the literature attributes. Nevertheless, according to Cramér's coefficient of association, there is no remarkable difference in the degree of correlation among these literature attributes.

Next, we estimate qualitative choice models to examine whether each literature attribute is correlated with the debate attitudes when the other attributes are simultaneously controlled. As explained in Section 3, the debate attitude of the step-by-step gradualism group, which puts forward the importance of policy sequence as its opposing axis to radicalism, has, theoretically, much clearer reasoning to support gradualism in comparison with that of the slow-paced

\footnotetext{
${ }^{16}$ It is also called Cramér's $V$. The value of this coefficient ranges from 0 to 1 . If it is closer to 1 , the association is evaluated to be stronger.
} 
gradualism group. Therefore, together with the relationship between the degree of the radicalism stance and literature attributes, it is valuable to examine the association between the degree to which policy sequence is stressed and the literature attributes among the studies produced by gradualists. Therefore, we use the following two types of dependent variables for our regression estimation: One is a four-point ordered variable that gives a value of 0 to the literature of gradualism, 1 to that of neutralism, 2 to that of conditional radicalism, and 3 to that of universal radicalism. This variable is used as a proxy for the degree of the radicalism stance. The other is a three-point ordered variable that captures the studies from the slow-paced gradualism group by 0 , those from the eclectic gradualism group by 1 , and those from the step-by-step gradualism group by 2 . This variable serves as a proxy for the degree to which policy sequence is stressed in the gradualists' research work.

As for the independent variable, we employ a total of 36 variables, which consist of 10 types of authorship attributes, 16 types of research content attributes, and 10 types of publication media attributes, which correspond with the row of cross tables in Table 1. Table 2 reports the type of variables used in our regression estimation, their descriptive statistics and correlation coefficients between each independent variable, and the two dependent variables. As shown in this table, both the degree of the radicalism stance and the degree to which policy sequence is stressed are closely associated with the seven types of variables. However, combinations of these significantly correlated independent variables are completely different between the two.

Table 3 reports estimation results of ordered probit models. Models [1] and [2] take the degree of the radicalism stance and the degree to which policy sequence is stressed as the dependent variable, respectively. We used the Huber-White sandwich estimator for computing robust standard errors. In this table, we report the most reliable models in terms of Akaike's information criterion (AIC) and Bayesian information criterion (BIC). ${ }^{17}$

The estimation results of Model [1] suggest the following relationship between the degree of the radicalism stance and the literature attributes in the basic collection: With regard to the authorship attributes, authors who belong to think tanks, the IMF, or the World Bank have a stronger tendency to support radicalism, as compared to authors who work for universities or for

\footnotetext{
${ }^{17}$ For a robustness check, we also performed an estimation of ordered logit models and found that the results are not much different from those in Table 3.
} 
academic research institutions. Similarly, as compared with authors based in Asia and Oceania, those based in other regions tend to attach a higher value to the radicalist approach. Moreover, Model [1] also indicates that authors whose first publication year is more recent are less likely to support radicalism, as is also true when an eminent economist is among the authors. ${ }^{18}$

Concerning the research content attributes, as compared to studies that discuss the transition strategy in general or without any particular subject regions, studies that explicitly deal with the FSU countries, Cuba, the Czech Republic or Czechoslovakia, Hungary, and Uzbekistan tend to express a more negative debate attitude against radicalism. In contrast, studies that discuss a transition strategy based on experiences or cases in China or Poland demonstrate a stronger support for radicalism. ${ }^{19}$ Furthermore, as compared with general policy studies, studies that argue for a transition strategy in line with the economic liberalization policy are more likely to express their support of radicalism, while studies that handle issues related to macroeconomic stabilization or enterprise reform and corporate restructuring tend to stress a negative stance toward radicalism. It is also proved that empirical examination is more frequently employed to endorse radicalism.

With respect to the publication media attributes, the estimation results of Model [1] imply that support for radicalism is more likely to be manifested in academic books, book chapters, and unpublished working papers than in journal articles. In addition, as compared with economicsrelated media, media that specialize in sociology or politics have a stronger tendency to carry views in favor of radicalism, while media devoted to business administration, and regional study are more likely to publish papers that distance themselves from radicalism. Moreover, it is also

\footnotetext{
${ }^{18}$ Though it has not yet been proven, it is possible that researchers of the post-socialism generation recognized that the situation during the early stage of transition in the countries required a shocktherapy strategy as a more critical phase than did those of the socialism generation. We also conjecture that eminent economists may have a tendency to avoid going so far as to advocate for a shock-therapy strategy, due to concern for their good reputations.

19 This result, indicating a close relationship between debate attitudes and focus on particular regions or countries, strongly suggests the possibility that both radicalists and gradualists purposefully choose a specific country or region that provides favorable evidence for their arguments. However, this result also suggests that China, which is regarded as a typical country that embraces gradualism, tends to be cited more often than other transition economies to support the radicalism-based transition strategy. As indicated in the cross table (f) in Table 1, this seemingly strange result comes from the fact that three studies on China express a neutral debate attitude.
} 
suggested from the estimates of Model [1] that publication media with a higher quality level tend to provide a platform to describe pro-radicalism discussions if other conditions remain unchanged.

To move on to the estimation results of Model [2], we point out the following relationship between the degree to which policy sequence is stressed and the literature attributes of the gradualism literature. First, as compared with authors who belong to universities or academic research institutions, staff members of international organizations who advocate gradualism pay more attention to the importance of policy sequence than to problems caused by hasty reforms. Second, research works that study the FSU states, Hungary, and Uzbekistan tend to advocate transition strategies based on slow-paced gradualism rather than on step-by-step gradualism. In contrast, studies that focus on Cuba or certain countries in Southeastern Europe are more likely to justify gradualism from the standpoint of step-by-step gradualism. Third, as compared with economics-related media, media that specialize in business administration and international relations more aggressively feature discussions that emphasize policy sequence, while politicsrelated media have a stronger inclination to feature opinions that stress the time allocation for promoting reforms.

To obtain deeper insights into the relationship between the degree to which policy sequence is stressed and the literature attributes within gradualism-advocating literature, we also estimated a multinomial logit choice model that sets the slow-paced gradualism group as its base category. Table 4 shows the results. According to this table, we can make additional remarks regarding the aforementioned observations earned from the ordered probit regression of Model [2]. The first point is that think tank staff members are more likely to construct arguments that rely on slowpaced gradualism rather than on step-by-step gradualism. Second, authors based in the CEE and FSU countries have a strong inclination to oppose radicalism from the viewpoint of policy sequence rather than the time allocation for reforms. Third, female researchers who support gradualism tend to participate in the transition strategy debate based on a slow-paced gradualism rather than a step-by-step gradualism; from this fact, we can see their inclination toward fearing the social disorder brought by reforms. Fourth, eminent economists have a tendency to express opinions in line with eclectic gradualism. Fifth, as compared with studies that discuss policies in general, papers that deal with a concrete policy measure put more emphasis on the time speed of reforms. Finally, media specializing in business administration and international relations as well 
as in sociology are more likely to publish studies that promote step-by-step gradualism rather than slow-pace gradualism, while media related to regional study as well as politics show the opposite relationship.

To summarize, there is close relationship between the debate attitudes and the literature attributes in the basic collection, and the findings reported in this section are helpful for understanding the background of the transition strategy debate and its path to date.

\section{Beyond the Dichotomy: Concluding Remarks}

The discussion of transition strategies still continues even now, more than a quarter of a century after the collapse of communism in the CEE and FSU region. Through an analytical survey of 137 related studies, we have presented an overall picture of the radicalism-versus-gradualism debate and examined the relationship between debate attitudes and the literature attributes among the preceding studies. We found that radicalists maintain their monolithic debate attitude from the viewpoints of time speed and policy sequence of the transition strategy, while the gradualists' debate attitude is more multifaceted. In fact, gradualists can be divided into the slow-paced gradualism group, the step-by-step gradualism group, and the eclectic gradualism group; the presence of these three groups is almost balanced. In addition, the debate content of the step-bystep gradualism group is more multi-layered than that of the remaining two groups, as it is comprised of the institutional gradualism group, which stresses that building institutions should take top priority over any other reform measures. Moreover, we also found that there is another group of researchers that stays within the framework of the radicalism-versus-gradualism debate while, at the same time, stays at arm's length from both the radicalists and the gradualists. However, these neutralists do not have much of a presence and, hence, the confrontation between radicalists and gradualists is remarkably vivid in the transition strategy debate.

Furthermore, the cross tabulation analysis and the regression estimation of qualitative choice models conducted in the previous section revealed interesting findings for deeper understanding of the transition strategy debate; that is, authorship attributes, including affiliated institutions, their locations, research experiences, and gender, as well as influence on the academic world are closely related both to the degree of the radicalism stance and the degree to which policy sequence 
is stressed among gradualists. It also becomes clear that studies that discuss a desirable mode of the transition strategy in line with a specific country or a policy area tend to express much clearer debate attitudes, as compared with general policy discussions. In addition, it is also proved that empirical examination is more frequently carried out to back up radicalism. In other words, the author profiles, research subjects, and methodologies are a major source of the diversified arguments regarding transition strategies during the last quarter century. Furthermore, we found that the types of publication media, their specialized study fields, and their quality level are significantly correlated with the likelihood for specific debate attitudes to be published. These results imply that a sort of publication selection bias may exist in this research area.

The radicalism-versus-gradualism debate has been developed through the production of a great number of research works characterized by the preceeding findings. In this way, it has not only served as a bellwether of academic argument on transition strategy, but it has also played a significant role in the creation of a new research field called transition economics. In recent years, a quarter of a century after the end of the Cold War, some researchers have even declared "the end of economic transition" (Sonin, 2013). Under these circumstances, it is difficult to deny that selection of the reform track is no longer a strategically important matter for the majority of CEE and FSU countries, in reality. On a global scale, however, some countries still maintain a strict socialist regime, and, in the near future, these countries might face political and economic issues similar to those with which the CEE and FSU countries struggled. In addition, radicalism and gradualism are never to be confined to the former socialist economies, but rather both policy philosophies can constitute an important platform for discussing structural reforms and other economic policies in developing countries. In some cases, they may be useful even for developed countries. In this sense, we strongly believe that the transition strategy debate, which has developed mainly through the study of the former socialist economies in the CEE and FSU regions and China, should be further deepened and systematized toward an upgrade to a more general policy theory.

In our view, one of urgent tasks that researchers must tackle to this end is to expand and enrich the empirical studies. As Panel (c) of Figure 2 shows, econometric studies account for only $10.9 \%$ of the entire basic collection, or 15 of the 137 preceding studies. This means that the transition strategy debate has thus far advanced without having sufficient empirical examinations. Lack of 
empirical evidence allows for discretion and arbitrariness by researchers and ultimately keeps the debate from converging. It is possible that the transition strategy debate has actually been trapped in this bottleneck. We understand that this kind of policy debate is difficult to fit into empirical analysis, due to its nature and scope. Nevertheless, we maintain that there is still much room for improvement in this aspect. ${ }^{20}$

Another task that may significantly contribute to further development of the transition strategy debate is the deconstruction of the traditional dichotomy. We agree that this conventional debate format is useful for both clarification of controversial issues and theoretical considerations. However, there are more than a few cases in which the understanding of the reality is excessively simplified and/or trivialized because of the enthusiasm to interpret every insight obtained from observations of transition economies within this framework. This adverse effect seems to be getting more pronounced as knowledge and data on the process of economic transition accumulate in larger quantities.

One possible breakthrough solution to this problem is provided by the third-way thinkers mentioned in Section 3. The dichotomy of radicalism versus gradualism implicitly presumes that all transition economies are aiming to establish a capitalist market economy as their ultimate goal. Only if this precondition is met are we allowed to classify all observable transition economies into three categories - radical reformers, gradual reformers, or intermediate reformers between the two-and then compare these country groups with each other. However, the third-way thinkers are trying to overcome serious contradictions caused by an unreasonable attempt to discuss all reform results and economic performances in transition countries within this traditional framework by explicitly identifying some former socialist countries (and China, in some researchers' views) as the other country group, which does not necessarily intend to introduce the capitalist market system.

A representative scholar among the third-way thinkers is Richard Pomfret, who clearly distinguished Uzbekistan from gradualism-based reforming countries. In Pomfret (2000), he stated that this Central Asian country adopted a development model that is less consistent with

\footnotetext{
${ }^{20}$ Reevaluation and meta-analysis of empirical evidence reported in previous studied that examined the impact of structural reforms on economic performance in transition economies are also valuable from this viewpoint. See Babecký and Campos (2011) and Babecky and Havranek (2014).
} 
the ideal gradualism. Nevertheless, the Uzbek economy was relatively stable throughout the early stage of transition. The key to such a better performance was its unique economic and industrial policies rather than the modest reform speed as stressed by many other researchers. Zettelmeyer (1999) also dealt with the uniqueness of Uzbekistan's way of transition. In this paper, he argued that Uzbekistan might have rebuilt its economy by a series of measures that does not match the gradualists' policy recommendations, indicating that the economic crisis that followed the collapse of the Soviet Union was relatively mild in Uzbekistan, due to the implementation of industrial policy that imposed a strong grip on production, in addition to some favorable preconditions including the country's underdevelopment and rich energy resources. Moreover, Herrmann-Pillath (2006) claimed that China's reform agenda does not set a transition to a capitalist market economy as the final goal, but rather its contents change flexibly and opportunistically, depending on the circumstances of the moment. Thus, he concluded that the Chinese way should be distinguished from the standard gradualism model.

We ourselves also discussed the economic performance and corruption in the FSU countries from a viewpoint similar to that of Pomfret (2000) and Zettelmeyer (1999) (Iwasaki, 2004; Iwasaki and Suzuki, 2007). Our arguments start from the fact that the FSU countries can be classified into two types of nations: The first consists of states that adopted a decentralization strategy and, according to this strategy, made efforts to restore their economic systems by devolving economic power grasped by the central government under socialism to domestic firms; the second consists of states that followed a recentralization strategy to fill the institutional vacuum that was brought about immediately after the breakdown of the Soviet Union by centralizing control over domestic firms in the hands of newly born independent governments and by restructuring industrial organizations to accommodate this change.

It is obvious that the decentralization strategy has a high affinity for the debate on radicalism versus gradualism, while the recentralization strategy cannot be handled within this traditional framework due to its heterogeneous nature. Belarus, Turkmenistan, and Uzbekistan have consistently pursued this recentralization strategy throughout the entire course of their transitions. These three countries are definitely different from the Baltic States, which have carried forward their decentralization strategy in a thorough manner, and the other FSU states including Russia, which share the same policy objective with the Baltic States, although they are lagging behind in 
terms of the separation between the state and enterprises. ${ }^{21}$ Therefore, it is highly effective to classify these three countries into a third country group, which belongs neither to the radicalismadopting countries nor to the gradualism-following countries, to avoid any misleading conclusions from handling their reform experiences in the framework of the orthodox dichotomy. In this sense, we and Myant and Drahokoupil (2010), who also clearly distinguish states that adopted the recentralization strategy from other transition countries from the same standpoint as ours, are third-way thinkers.

In order to promote the deconstruction of the transition strategy debate, we also need to listen to opinions from the transcendentalists, who raise a question about the raison d'être of the debate itself. For example, Hoen (1996) criticized the attempt to divide the former socialist countries into two categories, such as the Czech Republic and Poland as radical reformers and Hungary as a gradual reformer, as totally unrealistic, given the fact that both radicalism and gradualism are actually blended, depending on the policy areas in each transition country. From the same point of view, Louzek (2009) argued that it is inappropriate to classify transition economies as radicalism-based or gradualism-based reformers in reference to their respective privatization policies.

Meanwhile, Liodakis (2001) raised a question about the essence of the transition strategy debate from an angle substantially different from that of Hoen (1996) and Louzek (2009). He claimed that the radicalism-versus-gradualism debate is built on the premise of a transition from a socialist planned economy. According to him, however, economic transition in the CEE countries started with state capitalism; hence, the debate has missed the point in the first place. Taking additional steps forward, Leijonhufvud and Rühl (1997) expressed their severe view that the transition strategy debate is no longer of importance after a certain degree of advancement in

${ }^{21}$ As pointed out in Iwasaki (2004), in some cases, such as Azerbaijan and Tajikistan, the government tuned their reform strategies from recentralization to decentralization in the course of the economic transition. In Iwasaki (2004) and Iwasaki and Suzuki (2007), we called Belarus, Turkmenistan, and Uzbekistan, all of which adopted and carried out the recentralization strategy, Order States, in light of their top-down administration system in the relationship between the government and domestic companies. Meanwhile, the Baltic States, which established the principle of bringing bankrupt enterprises to justice based on the rule of law, are called Punish States. Russia and the other remaining former Soviet Republics, in which governments frequently take actions to rescue poorperforming companies due to the incomplete separation of the state-business relationship, are called Rescue States. 
marketization; thus, it makes no sense to continue the debate itself.

We believe that the transition strategy debate will further develop into a study area with richer contents and insights by going through the process of responding to bitter criticism from the transcendentalists as well as constructive suggestions from the third-way thinkers. We expect great progress in the future. 


\section{References}

Acemoglu, Daron, Davide Cantoni, Simon Johnson and James A. Robinson (2011), The consequences of radical reform: the French revolution, American Economic Review, 101:7, pp. 3286-3307.

Acemoglu, Daron, Simon Johnson, James A. Robinson and Pierre Yared (2008), Income and democracy, American Economic Review, 98:3, pp. 808-842.

Acemoglu, Daron and James A. Robinson (2012), Why nations fail: the origins of power, prosperity and poverty, Crown Publishers: New York.

Aghion, Philippe and Olivier J. Blanchard (1994), On the speed of transition in Central Europe, In: Fischer, Stanley and Julio J. Rotemberg (eds.), NBER Macroeconomics Annual 1994, Volume 9, MIT Press: Cambridge, Mass. and London, pp. 283-320.

Arrow, Kenneth J. (2000), Economic transition: speed and scope, Journal of Institutional and Theoretical Economics, 156:1, pp. 9-18.

Åslund, Anders (2007), How Capitalism Was Built: The Transformation of Central and Eastern Europe, Russia, and Central Asia, Cambridge University Press: New York.

Åslund, Anders (2009), Why market reform succeeded and democracy failed in Russia, Social Research, 76:1, pp. 1-28.

Åslund, Anders (2013), How Capitalism Was Built: The Transformation of Central and Eastern Europe, Russia, and Central Asia, Second Edition, Cambridge University Press: New York.

Babecký, Jan and Nauro F. Campos (2011), Does reform work? an econometric survey of the reformgrowth puzzle, Journal of Comparative Economics, 39:2, pp. 140-158.

Babecky, Jan and Tomas Havranek (2014), Structural reforms and growth in transition: a meta-analysis, Economics of Transition, 22:1, pp. 13-42.

Balcerowicz, Leszek (1994), Common fallacies in the debate on the transition to a market economy, Economic Policy, 9:19(Supplement), pp. 16-50.

Balcerowicz, Leszek and Alan Gelb (1995), Macropolicies in transition to a market economy: a threeyear perspective, In Bruno, Michael and Boris Pleskovič (eds.), Proceedings of the World Bank Annual Conference on Development Economics 1994, World Bank: Washington, D.C., pp. 21-44.

BenYishay, Ariel and Pauline Grosjean (2014), Initial endowments and economic reform in 27 postsocialist countries, Journal of Comparative Economics, 42:3, pp. 892-906.

Berg, Andrew, Eduardo Borensztein, Ratna Sahay and Jeromin Zettelmeyer (1999), The evolution of output in transition economies: explaining the differences, Working Paper No.WP/99/73, IMF: Wasington, D.C.

Bhagwati, Jagdish (1994), Shock treatments, New Republic, 210:13, pp. 39-43.

Blanchard, Oliver and Michael Kremer (1997), Disorganization, Quarterly Journal of Economics, 112:4, pp. 1091-1126.

Brada, Josef C. (1993), The transformation from communism to capitalism: how far? how fast? PostSoviet Affairs, 9:2, pp. 87-110.

Calcagno, Peter T., Frank Hefner and Marius Dan (2006), Restructuring before privatization - putting the cart before the horse: a case study of the steel industry in Romania, Quarterly Journal of Austrian Economics, 9:1, pp. 27-45.

Coyne, Christopher J. and Peter J. Boettke (2006), The role of the economist in economic development, Quarterly Journal of Austrian Economics, 9:2, pp. 47-68.

Dehejia, Vivek H. (1996), Shock therapy vs. gradualism: a neoclassical perspective, Eastern Economic Journal, 22:4, pp. 425-431.

de Melo, Martha, Cevdet Denizer and Alan Gelb (1996), Patterns of transition from plan to markrt, 
World Bank Economic Review, 10:3, pp. 397-424.

de Melo, Martha, Cevdet Denizer, Alan Gelb and Stoyan Tenev (2001), Circumstance and choice: the role of initial conditions and policies in transition economies, World Bank Economic Review, 15:1, pp. 1-31.

Dewatripont, Mathias and Gérard Roland (1992a), Economic reform and dynamic political constraints, Review of Economic Studies, 59:4, pp. 703-730.

Dewatripont, Mathias and Gérard Roland (1992b), The virtues of gradualism and legitimacy in the transition to a market economy, Economic Journal, 102:411, pp. 291-300.

Dewatripont, Mathias and Gérard Roland (1995), The design of reform packages under uncertainty, American Economic Review, 85:5, pp. 1207-1223.

Etzioni, Amitai (1992), How is Russia bearing up? Challenge, 35:3, pp. 40-43.

Fan, Gang (1994), Incremental changes and dual-track transition: understanding the case of China, Economic Policy, 9:19(Supplement), pp. 99-122.

Gel'vanovskii, Mikhail (1994), Russia on the path to a normal economic system, Problems of Economic Transition, 37:3, pp. 47-61.

Grosfeld, Irena and Ekaterina Zhuravskaya (2015), Cultural vs. economic legacies of empires: evidence from the partition of Poland, Journal of Comparative Economics, 43:1, pp. 55-75.

Hecht, James L. (1994), Shocked Russians, chagrined economists, Orbis, 38:3, pp. 499-504.

Herrmann-Pillath, Carsten (2006), Cultural species and institutional change in China, Journal of Economic Issues, 40:3, pp. 539-574.

Hoen, Herman W. (1996), Shock versus gradualism in the Central Europe reconsidered, Comparative Economic Studies, 38:1, pp. 1-20.

Hoen, Herman W. (2010), Transition strategies in Central Asia: is there such a thing as "shock-versusgradualism"? Economic and Environmental Studies, 10:2, pp. 229-245.

Islam, Shafiqul (1993), Russia's rough road to capitalism, Foreign Affairs, 72:2, pp. 57-66.

Iwasaki, Ichiro (2004), Evolution of the government-business relationship and economic performance in the former Soviet states: order state, rescue state, punish state, Economics of Planning, 36:3, pp. $223-257$.

Iwasaki, Ichiro and Taku Suzuki (2007), Transition strategy, corporate exploitation, and state capture: an empirical analysis of the former Soviet states, Communist and Post-Communist Studies, 40:4, pp. 393-422.

Iwasaki, Ichiro and Masahiro Tokunaga (2014), Macroeconomic impacts of FDI in transition economies: a meta-analysis, World Development, 61, pp. 53-69.

Jakšić, Miomir (2014), Political macroeconomy: the case of Serbia, Ekonomske Ideje i Praksa, 12, pp. 47-66.

King, Lawrence (2002), Postcommunist divergence: a comparative analysis of the transition to capitalism in Poland and Russia, Studies in Comparative International Development, 37:3, pp. 334.

Klaus, Vaclav (1993), Interplay of political and economic reform measures, Vital Speeches of the Day, 60:5, pp. 130-132.

Kornai, János (1994), Transformational recession: the main causes, Journal of Comparative Economics, 19:1, pp. 39-63.

Lavigne, Marie (2000), The economics of the transition process: what have we learned? Problems of Post-Communism, 47:4, pp. 16-23.

Leijonhufvud, Axel and Christof Rühl (1997), Russian dilemma, American Economic Review, 87:2, pp. 344-348. 
Lian, Peng and Shang-Jin Wei (1998), To shock or not to shock? economics and political economy of large-scale reforms, Economics and Politics, 10:2, pp. 161-183.

Liew, Leong H. (1995), Gradualism in China's economic reform and the role for a strong central state, Journal of Economic Issues, 29:3, pp. 883-895.

Liodakis, George (2001), The political economy of the transition and the transformation crisis in Eastern Europe, East-West Journal of Economics and Business, 4:2, pp. 45-64.

Lipton, David and Jeffrey D. Sachs (1990), Creating a market economy in Eastern Europe: the case of Poland, Brookings Papers on Economic Activity, 21:1, pp. 75-148.

Louzek, Marek (2009), The Czech privatisation after 20 years, Post-Communist Economies, 21:3, pp. 345-359.

Lütz, Susanne and Matthias Kranke (2014), The European rescue of the Washington consensus? EU and IMF lending to Central and Eastern European countries, Review of International Political Economy, 21:2, pp. 310-338.

Marangos, John (2003), Was shock therapy really a shock? Journal of Economic Issues, 37:4, pp. $943-$ 966.

Marangos, John (2004a), A post-keynesian approach to the transition process, Eastern Economic Journal, 30:3, pp. 441-465.

Marangos, John (2004b), Alternative Economic Models of Transition, Ashgate: Burlington, VA.

Marangos, John (2006), Was market socialism a feasible alternative for transition economies? International Journal of Political Economy, 35:3, pp. 64-88.

McMillan, John and Barry Naughton (1992), How to reform a planned economy: lessons from China, Oxford Review of Economic Policy, 8:1, pp. 130-143.

Minniti, Maria and Lidija Polutnik (2007), Currency conversion and the role of expectations: the case of Slovenia, Economic and Business Review, 9:1, pp. 5-21.

Molchanov, Mikhail A. (2005), Russia and globalization, Perspectives on Global Development and Technology, 4:3/4, pp. 397-429.

Murphy, Kevin M., Andrei Shleifer and Robert W. Vishny (1992), The transition to a market economy: pitfalls of partial reform, Quarterly Journal of Economics, 107:3, pp. 889-906.

Murrell, Peter (1992a), Evolutionary and radical approaches to economic reform, Economics of Planning, 25:1, pp. 79-95.

Murrell, Peter (1992b), Evolution in economics and in the economic reform of the centrally planned economies, In: Clague, Cristopher and Gordon C. Rausser (eds), The Emergence of Market Economies in Eastern Europe, Blackwell: Oxford, pp. 35-53.

Myant, Martin and Jan Drahokoupil (2010), Transition Economies: Political Economy in Russia, Eastern Europe, and Central Asia, J. Wiley: Hoboken, NJ.

Noman, Omar (1999), In the former eastern bloc, a hazardous transition, UNESCO Courier, 52:3, pp. 30-31.

North, Douglass C. (1994), Economic performance through time, American Economic Review, 84:3, pp. 359-368.

Papapanagos, Harry and Peter Sanfey (2003), Emigration and the optimal speed of transition, Review of International Economics, 11:3, pp. 541-554.

Pomfret, Richard (2000), The Uzbek model of economic development, 1991-1999, Economics of Transition, 8:3, pp. 733-748.

Popov, Vladimir (2000a), Shock therapy versus gradualism: the end of the debate (explaining the magnitude of transformational recession), Comparative Economic Studies, 42:1, pp. 1-57.

Popov, Vladimir (2000b), Shock therapy versus gradualism ten years down the road (book review of 
'From Shock to Therapy. The Political Economy of Postsocialist Transformation,' by Grzegorz W. Kolodko), Comparative Economic Studies, 42:3, pp. 121-125.

Popov, Vladimir (2007), Shock therapy versus gradualism reconsidered: lessons from transition economies after 15 years of reforms, Comparative Economic Studies, 49:1, pp. 1-31.

Popov, Vladimir (2009), Lessons from the transition economies: putting the success stories of the postcommunist world into a broader perspective, UNU-WIDER Research Paper No. RP2009/15, World Institute for Development Economics Research, United Nations University: Helsinki.

Popov, Vladimir (2012), Russia: austerity and deficit reduction in historical and comparative perspective, Cambridge Journal of Economics, 36:1, pp. 313-334.

Rodrik, Dani (2006), Goodbye Washington consensus, hello Washington confusion? a review of the World Bank's economic growth in the 1990s: learning from a decade of reform, Journal of Economic Literature, 44:4, pp. 973-987.

Rosefielde, Steven (2001), Premature deaths: Russia's radical economic transition in Soviet perspective, Europe-Asia Studies, 53:8, pp. 1159-1176.

Rozelle, Scott and Johan F. M. Swinnen (2009), Why did the communist party reform in China, but not in the Soviet Union? the political economy of agricultural transition, China Economic Review, 20:2, pp. 275-287.

Sachs, Jeffrey. D. (1996), The transition at mid decade, American Economic Review, 86:2, pp. 128133.

Selowsky, Marcelo and Ricardo Martin (1997), Policy performance and output growth in the transition economies, American Economic Review, 87:2, pp. 349-353.

Shleifer, Andrei and Daniel Treisman (2014), Normal countries: the east 25 years after communism, Foreign Affairs, 93:6, pp. 92-103.

Sonin, Konstantin (2013), The end of economic transition: lessons for future reformers and students of reform, Economics of Transition, 21:1, pp. 1-10.

Stiglitz, Joseph E. (1999), Whither reform? ten years of the transition, Annual Bank Conference on Development Economics, April 1999, World Bank: Washington, D.C.

Sušjan, Andrej and Tjaša Redek (2008), Uncertainty and growth in transition economies, Review of Social Economy, 66:2, pp. 209-234.

Svejnar, Jan (1989), A framework for the economic transformation of Czechoslovakia, PlanEcon Report, 5:52, pp. 1-18.

Swaan, Wim and Maria Lissowska (1996), Capabilities, routines, and East European economic reform: Hungary and Poland before and after the 1989 revolutions, Journal of Economic Issues, 30:4, pp. 1031-1056.

Turley, Gerard and Peter J. Luke (2010), Transition Economics: Two Decades On, Routledge: London and New York.

Van Brabant, Jozef M. (1993), Lessons from the wholesale transformations in the East, Comparative Economic Studies, 35:4, pp. 73-102.

Van Brabant, Jozef M. (1994a), Alternative trade regimes and the economics of transition, Russian and East European Finance and Trade, 30:1, pp. 32-52.

Van Brabant, Jozef M. (1994b), Bad debts and balance sheets in transforming Eastern Europe, Russian and East European Finance and Trade, 30:2, pp. 5-33.

Williamson, John (ed.) (1990), Latin American Adjustment: How Much Has Happened, Institute for International Economics: Washington, D.C.

Zettelmeyer, Jeromin (1999), The Uzbek growth puzzle, IMF Staff Papers, 46:3, pp. 274-292.

Zweynert, Joachim (2006), Shared mental models, catch-up development and economic policy- 
making: the case of Germany after World War II and its significance for contemporary Russia, Eastern Economic Journal, 32:3, pp. 457-478. 


\section{APPENDIX A COMPLETE LIST OF THE BASIC COLLECTION}

Aghion, Philippe and Olivier J. Blanchard (1994), On the speed of transition in Central Europe, In: Fischer, Stanley and Julio J. Rotemberg (eds.), NBER Macroeconomics Annual 1994, Volume 9, MIT Press: Cambridge, Mass. and London, pp. 283-320.

Ahrend, Rudiger (2005), Speed of reform, initial conditions or political orientation? explaining Russian regions' economic performance, Post-Communist Economies, 17:3, pp. 289-317.

Akimov, Alexandr and Brian E. Dollery (2008), Financial policy in transition economies: architecture, pace, and sequencing, Problems of Economic Transition, 50:9, pp. 6-26.

Alam, Quamrul, Thanh Hai Nguyen and Namul Majumdar (2009), Shock therapy versus gradualism: the Central Eastern Europe (CEE) and East Asia compared: a review of literature, International Business Research, 2:2, pp. 3-8.

Alvarez, José (2006), Privatization of state-owned agricultural enterprises in post-transition Cuba, Problems of Post-Communism, 53:6, pp. 30-45.

Arrow, Kenneth J. (2000), Economic transition: speed and scope, Journal of Institutional and Theoretical Economics, 156:1, pp. 9-18.

Åslund, Anders (2007), How Capitalism Was Built: The Transformation of Central and Eastern Europe, Russia, and Central Asia, Cambridge University Press: New York.

Åslund, Anders (2009), Why market reform succeeded and democracy failed in Russia, Social Research, 76:1, pp. 1-28.

Balcerowicz, Leszek (1994), Common fallacies in the debate on the transition to a market economy, Economic Policy, 9:19(Supplement), pp. 16-50.

Balcerowicz, Leszek and Alan Gelb (1995), Macropolicies in transition to a market economy: a threeyear perspective, In Bruno, Michael and Boris Pleskovič (eds.), Proceedings of the World Bank Annual Conference on Development Economics 1994, World Bank: Washington, D.C., pp. 21-44.

Berg, Andrew, Eduardo Borensztein, Ratna Sahay and Jeromin Zettelmeyer (1999), The evolution of output in transition economies: explaining the differences, Working Paper No.WP/99/73, IMF: Wasington, D.C.

Bernardes, Luis G. (2003), Reference-dependent preferences and the speed of economic liberalization, Journal of Socio-Economics, 32:5, pp. 521-548.

Bhagwati, Jagdish (1994), Shock treatments, New Republic, 210:13, pp. 39-43.

Blanchard, Oliver and Michael Kremer (1997), Disorganization, Quarterly Journal of Economics, 112:4, pp. 1091-1126.

Boycko, Maxim (1991), Price decontrol: the microeconomic case for the 'big bang' approach, Oxford Review of Economic Policy, 7:4, pp. 35-45.

Brada, Josef C. (1993), The transformation from communism to capitalism: how far? how fast? PostSoviet Affairs, 9:2, pp. 87-110.

Bruno, Randolph L. (2006), Optimal speed of transition with a shrinking labour force and under uncertainty, Economics of Transition, 14:1, pp. 69-100.

Buck, Trevor, Igor Filatotchev, Peter Nolan and Mike Wright (2000), Different paths to economic reform in Russia and China: causes and consequences, Journal of World Business, 35:4, pp. 379400.

Calcagno, Peter T., Frank Hefner and Marius Dan (2006), Restructuring before privatization - putting 
the cart before the horse: a case study of the steel industry in Romania, Quarterly Journal of Austrian Economics, 9:1, pp. 27-45.

Castanheira, Micael and Gérard Roland (2000), The optimal speed of transition: a general equilibrium analysis, International Economic Review, 41:1, pp. 219-239.

Chavance, Bernard (2008), Formal and informal institutional change: the experience of postsocialist transformation, European Journal of Comparative Economics, 5:1, pp. 57-71.

Chen, Ping (2008), Equilibrium illusion, economic complexity and evolutionary foundation in economic analysis, Evolutionary and Institutional Economics Review, 5:1, pp. 81-127.

Coyne, Christopher J. and Peter J. Boettke (2006), The role of the economist in economic development, Quarterly Journal of Austrian Economics, 9:2, pp. 47-68.

Csaba, László (2003), Transition as development, Post-Communist Economies, 15:1, pp. 3-25.

Csaba, László (2009), From sovietology to neo-institutionalism, Post-Communist Economies, 21:4, pp. 383-98.

Dabrowski, Marek (1996), Different strategies of transition to a market economy: how do they work in practice? Policy Research Working Paper No. WPS 1579, World Bank: Washington, D.C.

de Melo, Martha, Cevdet Denizer and Alan Gelb (1996), Patterns of transition from plan to markrt, World Bank Economic Review, 10:3, pp. 397-424.

de Melo, Martha, Cevdet Denizer, Alan Gelb and Stoyan Tenev (2001), Circumstance and choice: the role of initial conditions and policies in transition economies, World Bank Economic Review, 15:1, pp. 1-31.

Dehejia, Vivek H. (1996), Shock therapy vs. gradualism: a neoclassical perspective, Eastern Economic Journal, 22:4, pp. 425-431.

Dehejia, Vivek H. (2003), Will gradualism work when shock therapy doesn't? Economics and Politics, 15:1, pp. 33-59.

Dehejia, Vivek H. and Douglas W. Dwyer (2004), Output and unemployment dynamics in transition, Journal of Policy Reform, 7:2, pp. 69-81.

Dell'Anno, Roberto and Stefania Villa (2013), Growth in transition countries: big bang versus gradualism, Economics of Transition, 21:3, pp. 381-417.

Desai, Padma (1996), Book review of 'The Market Meets its Match: Restructuring the Economies of Eastern Europe' by Amsden, Alice H., Jacek Kochanowicz and Lance Taylor, Journal of Economic Literature, 34:1, pp. 181-182.

Dewatripont, Mathias and Gérard Roland (1992), Economic reform and dynamic political constraints, Review of Economic Studies, 59:4, pp. 703-730.

Dewatripont, Mathias and Gérard Roland (1992), The virtues of gradualism and legitimacy in the transition to a market economy, Economic Journal, 102:411, pp. 291-300.

Dewatripont, Mathias and Gérard Roland (1995), The design of reform packages under uncertainty, American Economic Review, 85:5, pp. 1207-1223.

Dickenson, R. Peter, David Campbell and Vladimir Azarov (2000), Will western managerial methods work in transitional societies? Problems of Post-Communism, 47:3, pp. 48-56.

Dunning, Thad and Grigore Pop-Eleches (2004), From transplants to hybrids: exploring institutional pathways to growth, Studies in Comparative International Development, 38:4, pp. 3-29.

Easterly, William (2006), The big push deja vu: a review of Jeffrey Sachs's the end of poverty: economic possibilities for our time, Journal of Economic Literature, 44:1, pp. 96-105.

Etzioni, Amitai (1992), How is Russia bearing up? Challenge, 35:3, pp. 40-43.

Fan, Gang (1994), Incremental changes and dual-track transition: understanding the case of China, Economic Policy, 9:19(Supplement), pp. 99-122. 
Ferragina, Anna M. and Francesco Pastore (2008), Mind the GAP: unemployment in the new EU regions, Journal of Economic Surveys, 22:1, pp. 73-113.

Fischer, Stanley and Alan Gelb (1991), The process of socialist economic transformation, Journal of Economic Perspectives, 5:4, pp. 91-105.

Gel'vanovskii, Mikhail (1994), Russia on the path to a normal economic system, Problems of Economic Transition, 37:3, pp. 47-61.

Glinavos, Ioannis (2010), Transition or development? reassessing priorities for law reform, Progress in Development Studies, 10:1, pp. 59-74.

Hall, Thomas W. and John E. Elliott (1999), Poland and Russia one decade after shock therapy, Journal of Economic Issues, 33:2, pp. 305-314.

Hare, Paul and Tamás Révész (1992), Hungary's transition to the market: the case against a 'big-bang', Economic Policy, 7:14, pp. 228-264.

Hecht, James L. (1994), Shocked Russians, chagrined economists, Orbis, 38:3, pp. 499-504.

Heliste, Piia, Paivi Karhunen and Riitta Kosonen (2008), Managing foreign business operations through institutional change from transition to post-transition: Finnish firms in Russia and Estonia, Journal of East-West Business, 14:1, pp. 65-99.

Ibrahim, Gamal and Vaughan Galt (2002), Bye-bye central planning, hello market hiccups: institutional transition in Romania, Cambridge Journal of Economics, 26:1, pp. 105-118.

Islam, Shafiqul (1993), Russia's rough road to capitalism, Foreign Affairs, 72:2, pp. 57-66.

Ivanova, Maria (2007), Inequality and government policies in Central and Eastern Europe, East European Quarterly, 41:2, pp. 167-204.

Jakšić, Miomir (2014), Political macroeconomy: the case of Serbia, Ekonomske Ideje i Praksa, 12, pp. 47-66.

Jin, Dengjian and Kingsley E. Haynes (1997), Economic transition at the edge of order and chaos: China's dualist and leading sectoral approach, Journal of Economic Issues, 31:1, pp. 79-101.

Johnson, Simon and Gary Loveman (1995), Starting over: Poland after communism, Harvard Business Review, 73:2, pp. 44-56.

Katz, Barbara G. and Joel Owen (2009), Are property rights enough? re-evaluating a big-bang claim, Economics of Transition, 17:1, pp. 75-96.

Kazemi, Leila (2003), Domestic sources of Uzbekistan's foreign policy, 1991 to the present, Journal of International Affairs, 56:2, pp. 205-216.

King, Lawrence (2002), Postcommunist divergence: a comparative analysis of the transition to capitalism in Poland and Russia, Studies in Comparative International Development, 37:3, pp. 334.

Klaus, Vaclav (1993), Interplay of political and economic reform measures, Vital Speeches of the Day, 60:5, pp. 130-132.

Koford, Kenneth (1997), Why the ex-communist countries should take the 'middle way' to the market economy, Eastern Economic Journal, 23:1, pp. 31-50.

Koźmiński, Andrzej K. (2011), Transition: unanswered questions, In: Kolodko, Grzegorz W. and Jacek Tomkiewicz (eds.), 20 Years of Transformation: Achievements, Problems and Perspectives, Nova Science Publishers: New York, pp. 133-148.

Lavigne, Marie (2000), The economics of the transition process: what have we learned? Problems of Post-Communism, 47:4, pp. 16-23.

Legge, John M. (2009), What next? D!ssent, 29, pp. 23-26.

$\mathrm{Li}, \mathrm{He}$ (2005), The Chinese path of economic reform and its implications, Asian Affairs: An American Review, 31:4, pp. 195-211. 
Lian, Peng and Shang-Jin Wei (1998), To shock or not to shock? economics and political economy of large-scale reforms, Economics and Politics, 10:2, pp. 161-183.

Liew, Leong H. (1995), Gradualism in China's economic reform and the role for a strong central state, Journal of Economic Issues, 29:3, pp. 883-895.

Lipton, David and Jeffrey D. Sachs (1990), Creating a market economy in Eastern Europe: the case of Poland, Brookings Papers on Economic Activity, 21:1, pp. 75-148.

Lo, Dic (1999), Reappraising the performance of China's state-owned industrial enterprises, 1980-96, Cambridge Journal of Economics, 23:6, pp. 693-718.

Looney, Robert (2004), The viability of economic shock therapy in Iraq, Challenge, 47:5, pp. 86-103.

Marangos, John (2001), International trade policies for transition economies: the post Keynesian alternative, Journal of Post Keynesian Economics, 23:4, pp. 689-704.

Marangos, John (2002), A political economy approach to the neoclassical model of transition, American Journal of Economics and Sociology, 61:1, pp. 259-276.

Marangos, John (2003), Price liberalization, monetary, and fiscal policies for transition economies: a post Keynesian perspective, Journal of Post Keynesian Economics, 25:3, pp. 449-469.

Marangos, John (2003), Was shock therapy really a shock? Journal of Economic Issues, 37:4, pp. 943966.

Marangos, John (2004), A post-keynesian approach to the transition process, Eastern Economic Journal, 30:3, pp. 441-465.

Marangos, John (2004), Was shock therapy consistent with democracy? Review of Social Economy, 62:2, pp. 221-243.

Marangos, John (2004), Alternative Economic Models of Transition, Ashgate: Burlington, VA.

Marangos, John (2005), A political economy approach to the neoclassical gradualist model of transition, Journal of Economic Surveys, 19:2, pp. 263-293.

Marangos, John (2006), Was market socialism a feasible alternative for transition economies? International Journal of Political Economy, 35:3, pp. 64-88.

Marangos, John (2011), Social change versus transition: the political economy of institutions and transitional economies, Forum for Social Economics, 40:1, pp. 119-137.

McMillan, John and Barry Naughton (1992), How to reform a planned economy: lessons from China, Oxford Review of Economic Policy, 8:1, pp. 130-143.

Millar, James R. (2001), Papa schaeg on economic reform in Russia: rethinking western advice, Problems of Post-Communism, 48:3, pp. 3-9.

Minniti, Maria and Lidija Polutnik (2007), Currency conversion and the role of expectations: the case of Slovenia, Economic and Business Review, 9:1, pp. 5-21.

Mitrović, Radmila Dragutinović and Olgica Ivančev (2010), Driving forces of economic growth in the second decade of transition, Economic Annals, 55:185, pp. 7-32.

Molchanov, Mikhail A. (2005), Russia and globalization, Perspectives on Global Development and Technology, 4:3/4, pp. 397-429.

Morita, Tsuneo (2009), Facts and lessons of ten years of transformation in Central Europe, In: Ichimura, Shinichi, Tsuneaki Sato and William James (eds.), Transition from Socialist to Market Economies: Comparison of European and Asian Experiences, Palgrave Macmillan: Basingstoke, pp. 231-253.

Murphy, Kevin M., Andrei Shleifer and Robert W. Vishny (1992), The transition to a market economy: pitfalls of partial reform, Quarterly Journal of Economics, 107:3, pp. 889-906.

Murrell, Peter (1992), Evolutionary and radical approaches to economic reform, Economics of Planning, 25:1, pp. 79-95.

Murrell, Peter (1992), Evolution in economics and in the economic reform of the centrally planned 
economies, In: Clague, Cristopher and Gordon C. Rausser (eds), The Emergence of Market Economies in Eastern Europe, Blackwell: Oxford, pp. 35-53.

Murrell, Peter and Yijiang Wang (1993), When privatization should be delayed: the effect of communist legacies on organizational and institutional reforms, Journal of Comparative Economics, 17:2, pp. 385-406.

Myant, Martin and Jan Drahokoupil (2010), Transition Economies: Political Economy in Russia, Eastern Europe, and Central Asia, J. Wiley: Hoboken, NJ.

Noman, Omar (1999), In the former eastern bloc, a hazardous transition, UNESCO Courier, 52:3, pp. 30-31.

North, Douglass C. (1994), Economic performance through time, American Economic Review, 84:3, pp. 359-368.

Paganelli, Maria Pia (2012), Economies in transition and in development: a possible warning from Adam Smith, European Journal of the History of Economic Thought, 19:2, pp. 149-163.

Papapanagos, Harry and Peter Sanfey (2003), Emigration and the optimal speed of transition, Review of International Economics, 11:3, pp. 541-554.

Papava, Vladimer (2005), On the theory of post-communist economic transition to market, International Journal of Social Economics, 32:1/2, pp. 77-97.

Podkaminer, Leon (1995), Household behavior under 'austerity' stabilization of hyperinflation: the roots of fragility, Journal of Post Keynesian Economics, 17:4, pp. 593-605.

Poirot, Clifford (1996), Macroeconomic policy in a transitional environment: Romania, 1989-1994, Journal of Economic Issues, 30:4, pp. 1057-1075.

Polterovich, Victor (2012), Reform design: how to search for interim institutions, Montenegrin Journal of Economics, 8:2, pp. 25-44.

Popov, Vladimir (2000), Shock therapy versus gradualism ten years down the road (book review of 'From Shock to Therapy. The Political Economy of Postsocialist Transformation,' by Grzegorz W. Kolodko), Comparative Economic Studies, 42:3, pp. 121-125.

Popov, Vladimir (2000), Shock therapy versus gradualism: the end of the debate (explaining the magnitude of transformational recession), Comparative Economic Studies, 42:1, pp. 1-57.

Popov, Vladimir (2007), Shock therapy versus gradualism reconsidered: lessons from transition economies after 15 years of reforms, Comparative Economic Studies, 49:1, pp. 1-31.

Popov, Vladimir (2009), Lessons from the transition economies: putting the success stories of the postcommunist world into a broader perspective, UNU-WIDER Research Paper No. RP2009/15, World Institute for Development Economics Research, United Nations University: Helsinki.

Popov, Vladimir (2012), Russia: austerity and deficit reduction in historical and comparative perspective, Cambridge Journal of Economics, 36:1, pp. 313-334.

Rohac, Dalibor (2012), Economic transitions: learning from Central Europe, Policy Review, No. 175, pp. 69-79.

Rojec, Matija, Janez Sustersic, Bostjan Vasle, Marijana Bednas and Slavica Jurancic (2004), The rise and decline of gradualism in Slovenia, Post-Communist Economies, 16:4, pp. 459-482.

Roland, Gérard (2002), The political economy of transition, Journal of Economic Perspectives, 16:1, pp. 29-50.

Rosefielde, Steven (2001), Premature deaths: Russia's radical economic transition in Soviet perspective, Europe-Asia Studies, 53:8, pp. 1159-1176.

Rozelle, Scott and Johan F. M. Swinnen (2009), Why did the communist party reform in China, but not in the Soviet Union? the political economy of agricultural transition, China Economic Review, 20:2, pp. 275-287. 
Rutland, Peter (2013), Neoliberalism and the Russian transition, Review of International Political Economy, 20:2, pp. 332-362.

Sachs, Jeffrey D. and Wing Thye Woo (1994), Structural factors in the economic reforms of China, Eastern Europe, and the Former Soviet Union, Economic Policy, 9:18, pp. 101-145.

Sachs, Jeffrey. D. (1996), The transition at mid decade, American Economic Review, 86:2, pp. 128133.

Sau, Lino (2012), Evolution of china's financial system and its impact on economic development, International Journal of Economic Policy in Emerging Economies, 5:1, pp. 1-15.

Schusselbauer, Gerhard (1999), Privatisation and restructuring in economies in transition: theory and evidence revisited, Europe-Asia Studies, 51:1, pp. 65-83.

Selowsky, Marcelo and Ricardo Martin (1997), Policy performance and output growth in the transition economies, American Economic Review, 87:2, pp. 349-353.

Shleifer, Andrei and Daniel Treisman (2014), Normal countries: the east 25 years after communism, Foreign Affairs, 93:6, pp. 92-103.

Sokol, Martin (2001), Central and Eastern Europe a decade after the fall of state-socialism: regional dimensions of transition processes, Regional Studies, 35:7, pp. 645-655.

Sonin, Konstantin (2013), The end of economic transition: lessons for future reformers and students of reform, Economics of Transition, 21:1, pp. 1-10.

Spechler, Martin C. (2000), Uzbekistan: the silk road to nowhere, Contemporary Economic Policy, 18:3, pp. 295-303.

Spechler, Martin C. (2000), Hunting for the Central Asian tiger, Comparative Economic Studies, 42:3, pp. 101-120.

Stiglitz, Joseph E. (1999), Whither reform? ten years of the transition, Annual Bank Conference on Development Economics, April 1999, World Bank: Washington, D.C.

Sušjan, Andrej and Tjaša Redek (2008), Uncertainty and growth in transition economies, Review of Social Economy, 66:2, pp. 209-234.

Šušteršič, Janez (2009), Endogenous gradualism and the Slovenian puzzle, China Economic Review, $20: 2$, pp. 265-274.

Svejnar, Jan (1989), A framework for the economic transformation of Czechoslovakia, PlanEcon Report, 5:52, pp. 1-18.

Tomer, John F. (2002), Intangible factors in the Eastern European transition: a socio-economic analysis, Post-Communist Economies, 14:4, pp. 421-444.

Tompson, William (2002), Was Gaidar really necessary? Russian "shock therapy" reconsidered, Problems of Post-Communism, 49:4, pp. 12-21.

Tridico, Pasquale (2012), Varieties of capitalism and development in transition economies since the fall of the Berlin wall, Challenge, 55:3, pp. 90-128.

Turley, Gerard and Peter J. Luke (2010), Transition Economics: Two Decades On, Routledge: London and New York.

Uhlir, David (1998), Internationalization, and institutional and regional change: restructuring postcommunist networks in the region of Lanskroun, Czech Republic, Regional Studies, 32:7, pp. 673685 .

Uvalic, Milica (2012), Serbia's transition to market economy: why has the model not delivered? Montenegrin Journal of Economics, 8:2, pp. 87-98.

Van Brabant, Jozef M. (1993), Lessons from the wholesale transformations in the East, Comparative Economic Studies, 35:4, pp. 73-102.

Van Brabant, Jozef M. (1994), Alternative trade regimes and the economics of transition, Russian and 
East European Finance and Trade, 30:1, pp. 32-52.

Van Brabant, Jozef M. (1994), Bad debts and balance sheets in transforming Eastern Europe, Russian and East European Finance and Trade, 30:2, pp. 5-33.

Wei, Shang-Jin (1997), Gradualism versus big bang: speed and sustainability of reforms, Canadian Journal of Economics, 30:4, pp. 1234-1247.

Weisskopf, Thomas E. (1992), Russia in transition: perils of the fast track to capitalism, Challenge, 35:6, pp. 28-37.

Wolf, Holger. C. (1999), Transition strategies: choices and outcomes, Princeton Studies in International Finance No. 85, Department of Economics, Princeton University: Princeton, NJ.

Wyplosz, Charles (2000), Ten years of transformation: macroeconomic lessons, CEPR Discussion Paper No. DP2254, Centre for Economic Policy Research: London.

Zweynert, Joachim (2006), Shared mental models, catch-up development and economic policymaking: the case of Germany after World War II and its significance for contemporary Russia, Eastern Economic Journal, 32:3, pp. 457-478. 


\section{APPENDIX B METHOD FOR EVALUATING THE QUALITY LEVEL OF A PUBLICATION MEDIA}

This appendix describes the evaluation method used to determine the quality level of the publication media of the studies subjected to our meta-analysis.

For journal articles, we used the ranking of economics journals that had been published as of November 1, 2012, by IDEAS - the largest bibliographic database dedicated to economics and available freely on the Internet (http://ideas.repec.org/) — as the most basic information source for our evaluation of quality level. IDEAS provides the world's most comprehensive ranking of economics journals, and as of November 2012, 1173 academic journals were ranked.

We divided these 1173 journals into 10 clusters using a cluster analysis based on overall evaluation scores, and assigned each of these journal clusters a score (weight) from 1 (the lowest journal cluster) to 10 (the highest).

For academic journals that are not ranked by IDEAS, we referred to the Thomson Reuters Impact Factor and other journal rankings and identified the same level of IDEAS ranking-listed journals that correspond to these non-listed journals; we have assigned each of them the same score as its counterparts.

Meanwhile, for academic books and book chapters, we have assigned a score of 1 in principle, but if at least one of the following conditions is met, each of the relevant books or chapters has uniformly received a score of 4 , which is the median value of the scores assigned to the abovementioned IDEAS ranking-listed economics journals: (1) The academic book or book chapter clearly states that it has gone through the peer review process; (2) its publisher is a leading academic publisher that has external evaluations carried out by experts; or (3) the research level of the study has been evaluated by the authors to be obviously high. 
Figure 1. Frequency distribution of publication years of all searched literature and the basic collection

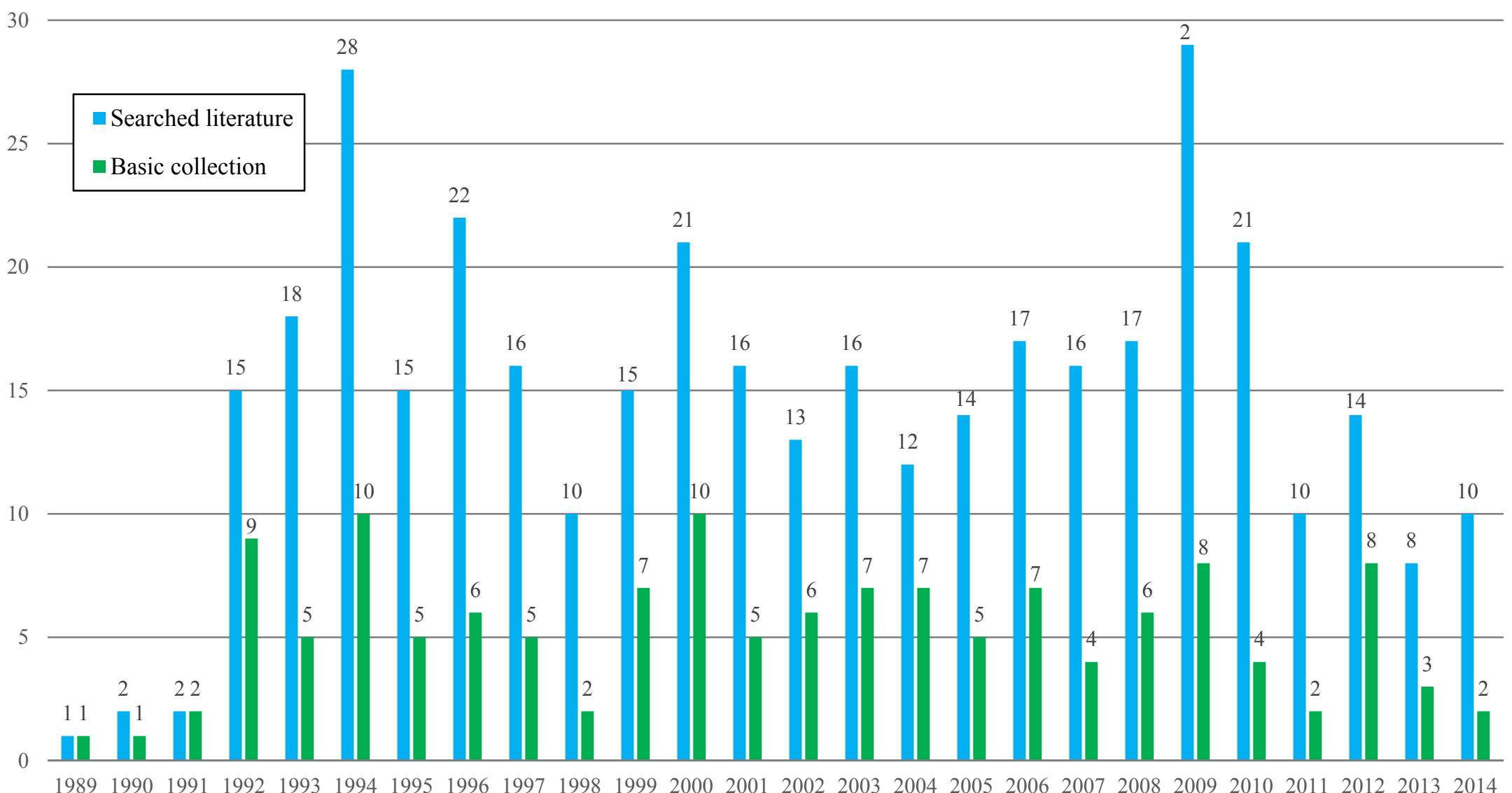


Figure 2. Breakdown of the basic collection by literature attribute ${ }^{\mathrm{a}}$

(a) Authorship attributes



(b) Research content attributes

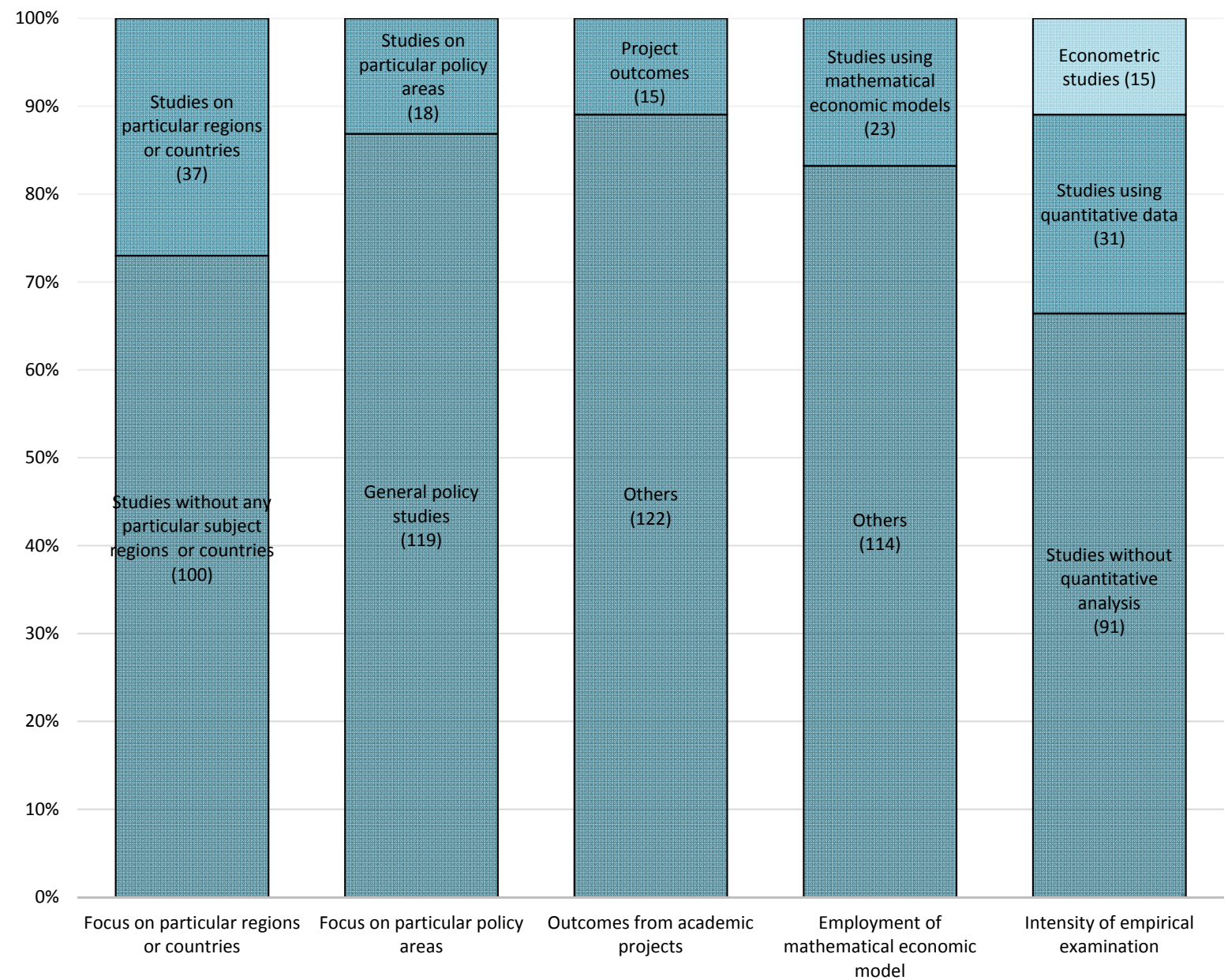


(c) Publication media attributes

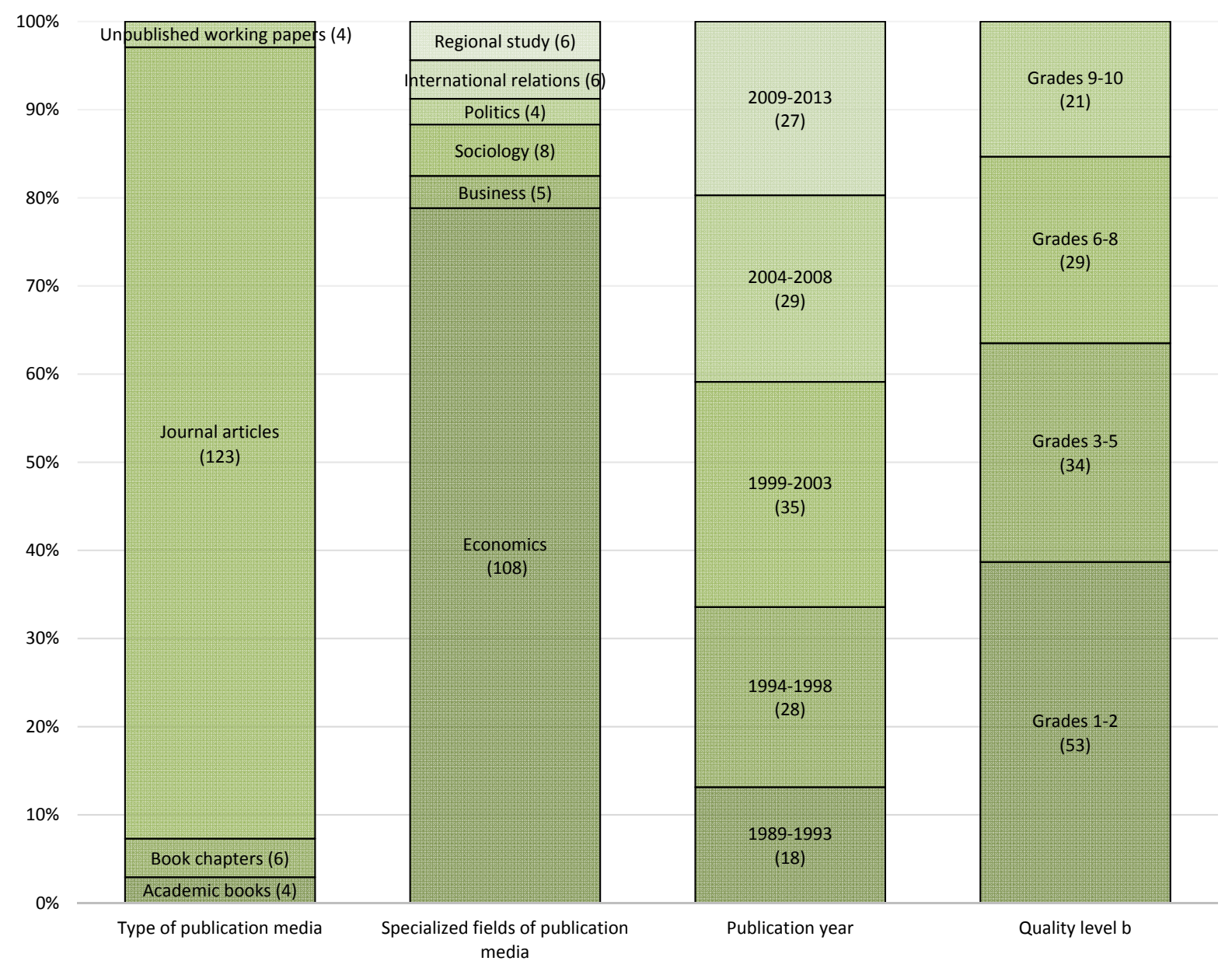

${ }^{a}$ Numbers in parentheses are those of the relevant literature.

${ }^{\mathrm{b}}$ For more details on the evaluation method, see Appendix B. 
Figure 3. Overall structure of the transition strategy debate

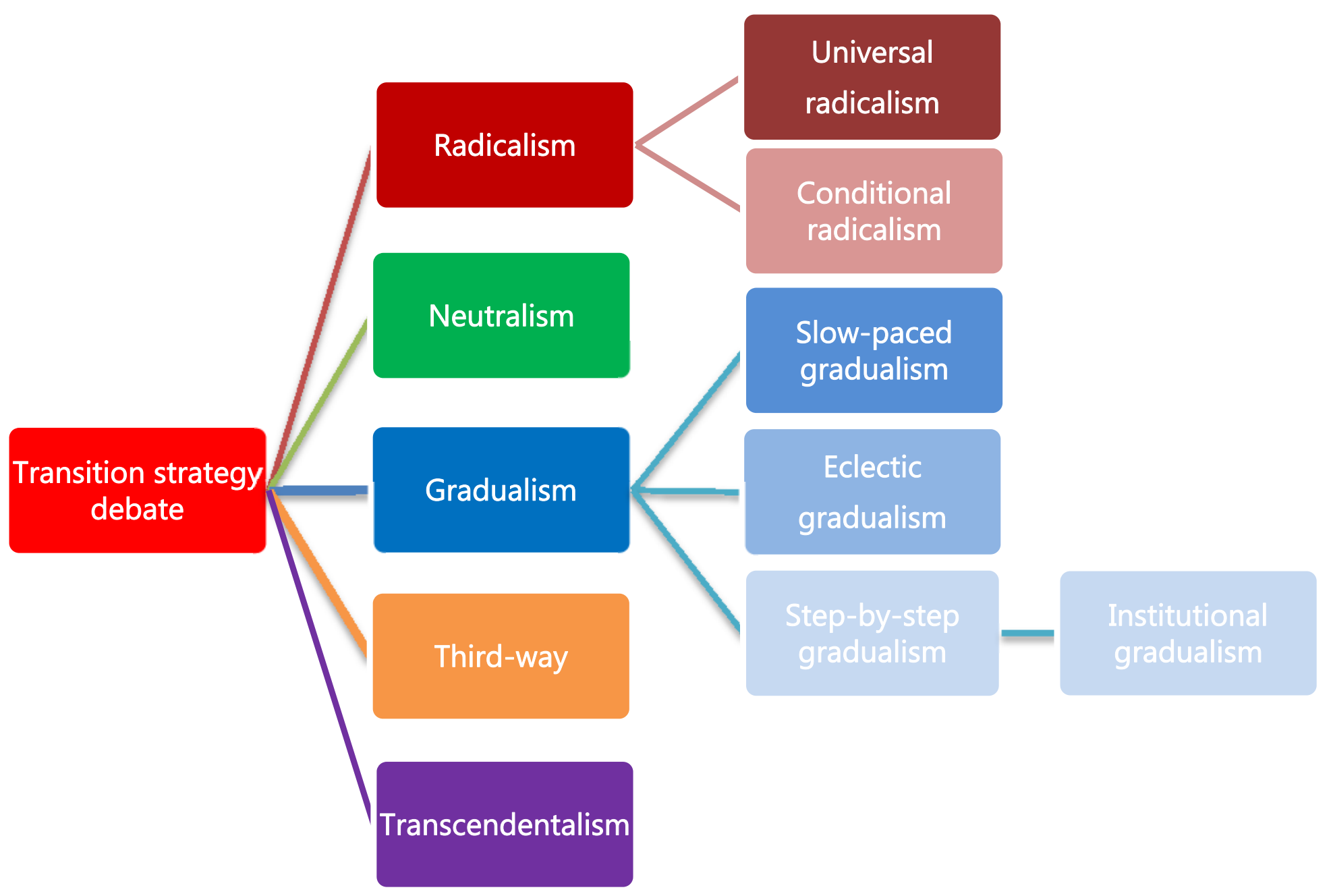


Figure 4. Breakdown of the basic collection by debate attitude
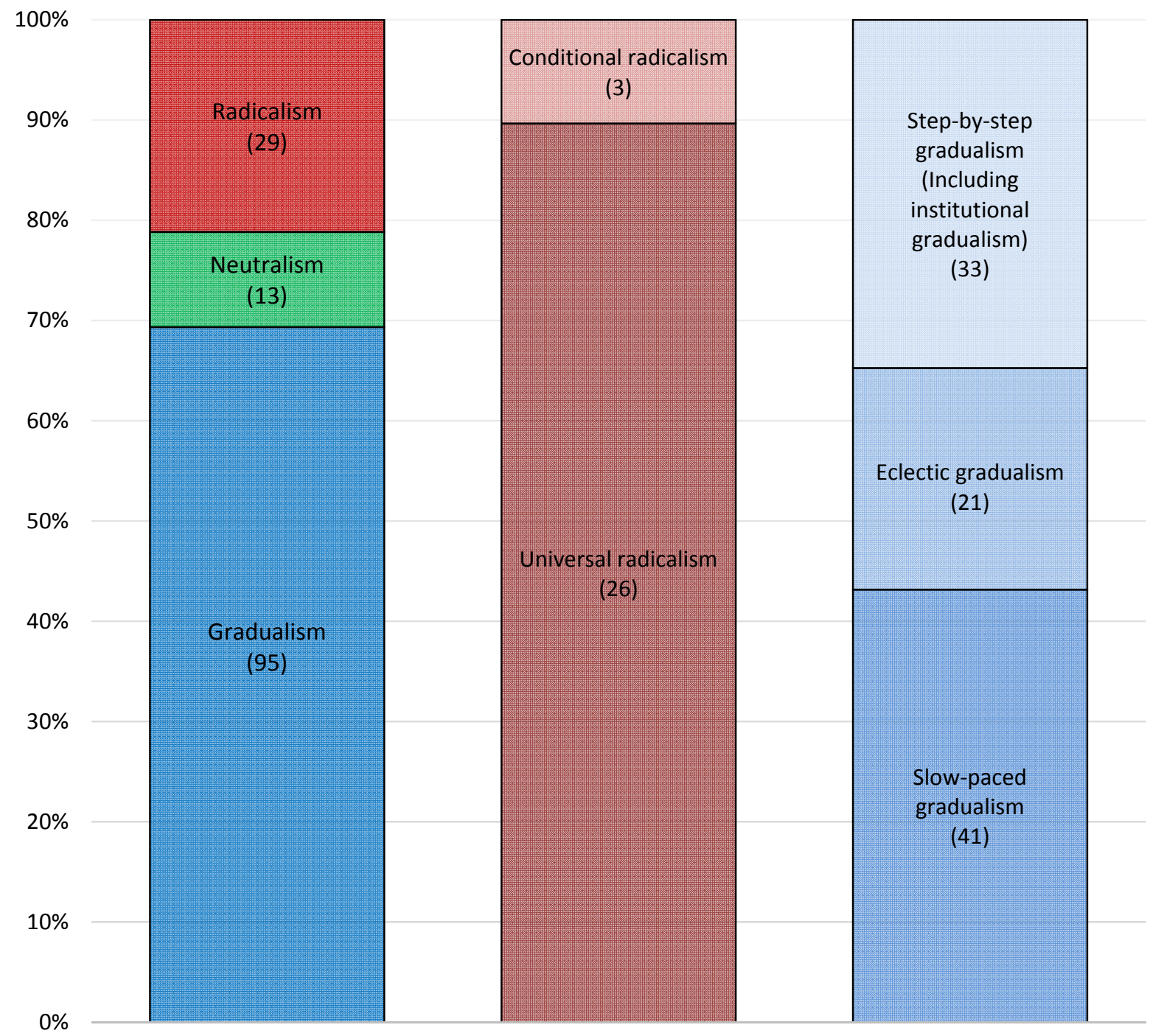

(a) Basic collection

(b) Radicalism

(c) Gradualism

Note: Numbers in parentheses are those of the relevant literature. 
Table 1. Cross tabulation analysis of the relationship between the debate attitudes and the literature attributes

\begin{tabular}{|c|c|c|c|c|c|c|c|c|c|c|c|}
\hline & \multicolumn{3}{|c|}{ Radicalism } & \multirow[b]{2}{*}{$\begin{array}{c}\text { Neutralism } \\
\text { (2) }\end{array}$} & \multicolumn{4}{|c|}{ Gradualism } & \multirow[b]{2}{*}{ Total } & \multirow{2}{*}{$\begin{array}{c}\text { Test I }^{\mathrm{a}} \\
\text { Upper: Chi-square } \\
\text { test of } \\
\text { independence } \\
\text { Lower: Cramér's } \\
\text { coefficient of } \\
\text { association }^{\mathrm{c}}\end{array}$} & \multirow{2}{*}{$\begin{array}{c}\text { Test II }^{\mathrm{b}} \\
\text { Upper: Chi-square } \\
\text { test of } \\
\text { independence } \\
\text { Lower: Cramér's } \\
\text { coefficient of }^{\text {association }}{ }^{\mathrm{c}} \\
\text { ass }^{\text {a }}\end{array}$} \\
\hline & $\begin{array}{l}\text { Total of } \\
\text { radicalism } \\
\text { (1) }\end{array}$ & $\begin{array}{l}\text { Universal } \\
\text { radicalism } \\
\text { (1a) }\end{array}$ & $\begin{array}{c}\text { Conditional } \\
\text { radicalism } \\
\text { (1b) }\end{array}$ & & $\begin{array}{c}\text { Total of } \\
\text { gradualism } \\
\text { (3) }\end{array}$ & $\begin{array}{l}\text { Slow-paced } \\
\text { gradualism } \\
\text { (3a) }\end{array}$ & $\begin{array}{l}\text { Eclectic } \\
\text { gradualism } \\
\text { (3b) }\end{array}$ & $\begin{array}{l}\text { Step-by- } \\
\text { step } \\
\text { gradualism } \\
\text { (3c) }\end{array}$ & & & \\
\hline \multicolumn{12}{|l|}{ (a) Affiliated institutions } \\
\hline Universities or academic research institutions & 24 & 22 & 2 & 20 & 116 & 48 & 26 & 42 & 160 & & \\
\hline Think tanks & 6 & 6 & 0 & 1 & 4 & 3 & 0 & 1 & 11 & & \\
\hline IMF or World Bank & 14 & 14 & 0 & 1 & 1 & 0 & 1 & 0 & 16 & & \\
\hline Other international institutions & 1 & 1 & 0 & 1 & 4 & 0 & 0 & 4 & 6 & & \\
\hline Others & 2 & 1 & 1 & 0 & 1 & 1 & 0 & 0 & 3 & $51.882^{* * *}$ & $83.510^{* * *}$ \\
\hline Total & 47 & 44 & 3 & 23 & 126 & 52 & 27 & 47 & 196 & 0.364 & 0.326 \\
\hline \multicolumn{12}{|l|}{ (b) Location of affiliated institutions } \\
\hline North America or Western Europe & 38 & 38 & 0 & 15 & 99 & 43 & 24 & 32 & 152 & & \\
\hline CEE & 7 & 5 & 2 & 6 & 7 & 3 & 0 & 4 & 20 & & \\
\hline FSU & 2 & 1 & 1 & 1 & 6 & 1 & 0 & 5 & 9 & & \\
\hline Asia and Oceania & 0 & 0 & 0 & 1 & 14 & 5 & 3 & 6 & 15 & $15.818^{* *}$ & $41.310^{* * *}$ \\
\hline Total & 47 & 44 & 3 & 23 & 126 & 52 & 27 & 47 & 196 & 0.201 & 0.265 \\
\hline \multicolumn{12}{|l|}{ (c) Median value of authors' first publication year } \\
\hline Until the $1960 \mathrm{~s}$ & 0 & 0 & 0 & 1 & 4 & 1 & 3 & 0 & 5 & & \\
\hline 1970s & 7 & 7 & 0 & 5 & 22 & 8 & 4 & 10 & 34 & & \\
\hline $1980 \mathrm{~s}$ & 13 & 12 & 1 & 2 & 15 & 7 & 5 & 3 & 30 & & \\
\hline $1990 \mathrm{~s}$ & 6 & 4 & 2 & 4 & 39 & 20 & 7 & 12 & 49 & & \\
\hline 2000s and after & 3 & 3 & 0 & 1 & 15 & 5 & 2 & 8 & 19 & $15.188^{*}$ & $32.487^{* *}$ \\
\hline Total & 29 & 26 & 3 & 13 & 95 & 41 & 21 & 33 & 137 & 0.235 & 0.243 \\
\hline (d) Involvement of female researchers & & & & & & & & & 0 & & \\
\hline Yes & 6 & 6 & 0 & 3 & 8 & 5 & 1 & 2 & 17 & & \\
\hline No & 23 & 20 & 3 & 10 & 87 & 36 & 20 & 31 & 120 & 4.581 & 6.864 \\
\hline Total & 29 & 26 & 3 & 13 & 95 & 41 & 21 & 33 & 137 & 0.183 & 0.224 \\
\hline \multicolumn{12}{|l|}{ (e) Involvement of world-famous economists ${ }^{d}$} \\
\hline Yes & 7 & 7 & 0 & 3 & 18 & 6 & 8 & 4 & 28 & & \\
\hline No & 22 & 19 & 3 & 10 & 77 & 35 & 13 & 29 & 109 & 0.430 & 7.778 \\
\hline Total & 29 & 26 & 3 & 13 & 95 & 41 & 21 & 33 & 137 & 0.056 & 0.238 \\
\hline \multicolumn{12}{|l|}{ (f) Focus on particular regions or countries } \\
\hline Without any particular subject regions & 23 & 20 & 3 & 8 & 69 & 29 & 15 & 25 & 100 & & \\
\hline FSU bloc & 0 & 0 & 0 & 0 & 2 & 1 & 1 & 0 & 2 & & \\
\hline China & 0 & 0 & 0 & 3 & 4 & 1 & 2 & 1 & 7 & & \\
\hline Cuba & 0 & 0 & 0 & 0 & 1 & 0 & 0 & 1 & 1 & & \\
\hline Czech Republic or Czechoslovakia & 0 & 0 & 0 & 0 & 2 & 1 & 1 & 0 & 2 & & \\
\hline Hungary & 0 & 0 & 0 & 0 & 1 & 1 & 0 & 0 & 1 & & \\
\hline Poland & 2 & 2 & 0 & 0 & 0 & 0 & 0 & 0 & 2 & & \\
\hline Certain countries in Southeastern Europe & 0 & 0 & 0 & 1 & 6 & 1 & 0 & 5 & 7 & & \\
\hline Russia & 4 & 4 & 0 & 1 & 7 & 4 & 2 & 1 & 12 & & \\
\hline Uzbekistan & 0 & 0 & 0 & 0 & 3 & 3 & 0 & 0 & 3 & 24.655 & 51.617 \\
\hline Total & 29 & 26 & 3 & 13 & 95 & 41 & 21 & 33 & 137 & 0.300 & 0.275 \\
\hline
\end{tabular}




\begin{tabular}{|c|c|c|c|c|c|c|c|c|c|c|c|}
\hline & \multicolumn{3}{|c|}{ Radicalism } & \multirow[b]{2}{*}{$\begin{array}{l}\text { Neutralism } \\
\text { (2) }\end{array}$} & \multicolumn{4}{|c|}{ Gradualism } & \multirow[b]{2}{*}{ Total } & \multirow[b]{2}{*}{$\begin{array}{c}\text { Test I }^{\text {a }} \\
\text { Upper: Chi-square } \\
\text { test of } \\
\text { independence } \\
\text { Lower: Cramér's } \\
\text { coefficient of }^{\text {association }}{ }^{\mathrm{c}}\end{array}$} & \multirow{2}{*}{$\begin{array}{c}\text { Test II }^{\mathrm{b}} \\
\text { Upper: Chi-square } \\
\text { test of } \\
\text { independence } \\
\text { Lower: Cramér's } \\
\text { coefficient of }^{\text {as }} \\
\text { association }^{\mathrm{c}}\end{array}$} \\
\hline & $\begin{array}{l}\text { Total of } \\
\text { radicalism } \\
\text { (1) }\end{array}$ & $\begin{array}{l}\text { Universal } \\
\text { radicalism } \\
\text { (1a) }\end{array}$ & $\begin{array}{l}\text { Conditional } \\
\text { radicalism } \\
\text { (1b) }\end{array}$ & & $\begin{array}{l}\text { Total of } \\
\text { gradualism } \\
\text { (3) }\end{array}$ & $\begin{array}{l}\text { Slow-paced } \\
\text { gradualism } \\
\text { (3a) }\end{array}$ & $\begin{array}{l}\text { Eclectic } \\
\text { gradualism } \\
\text { (3b) }\end{array}$ & $\begin{array}{l}\text { Step-by- } \\
\text { step } \\
\text { gradualism } \\
\text { (3c) }\end{array}$ & & & \\
\hline \multicolumn{12}{|l|}{ (g) Focus on particular policy areas } \\
\hline Policies in general & 26 & 24 & 2 & 12 & 81 & 36 & 19 & 26 & 119 & & \\
\hline Economic liberalization & 2 & 1 & 1 & 0 & 0 & 0 & 0 & 0 & 2 & & \\
\hline Macroeconomic stabilization & 1 & 1 & 0 & 0 & 5 & 2 & 1 & 2 & 6 & & \\
\hline Privatization & 0 & 0 & 0 & 1 & 4 & 2 & 0 & 2 & 5 & & \\
\hline Enterprise reform and corporate restructuring & 0 & 0 & 0 & 0 & 5 & 1 & 1 & 3 & 5 & 12.276 & $32.534^{* *}$ \\
\hline Total & 29 & 26 & 3 & 13 & 95 & 41 & 21 & 33 & 137 & 0.212 & 0.244 \\
\hline \multicolumn{12}{|l|}{ (h) Outcomes from academic projects } \\
\hline Project outcomes & 1 & 0 & 1 & 3 & 11 & 5 & 3 & 3 & 15 & & \\
\hline Others & 28 & 26 & 2 & 10 & 84 & 36 & 18 & 30 & 122 & 3.673 & 7.122 \\
\hline Total & 29 & 26 & 3 & 13 & 95 & 41 & 21 & 33 & 137 & 0.164 & 0.228 \\
\hline \multicolumn{12}{|l|}{ (i) Employment of mathematical economic models } \\
\hline Studies using mathematical economic models & 4 & 3 & 1 & 3 & 16 & 9 & 6 & 1 & 23 & & \\
\hline Others & 25 & 23 & 2 & 10 & 79 & 32 & 15 & 32 & 114 & 0.554 & 8.810 \\
\hline Total & 29 & 26 & 3 & 13 & 95 & 41 & 21 & 33 & 137 & 0.064 & 0.254 \\
\hline \multicolumn{12}{|l|}{ (j) Intensity of empirical examination } \\
\hline Econometric studies & 10 & 10 & 0 & 1 & 4 & 2 & 0 & 2 & 15 & & \\
\hline Studies using quantitative data & 5 & 5 & 0 & 2 & 24 & 11 & 7 & 6 & 31 & & \\
\hline Studies without quantitative analysis & 14 & 11 & 3 & 10 & 67 & 28 & 14 & 25 & 91 & $21.594^{* * *}$ & $29.069^{* * *}$ \\
\hline Total & 29 & 26 & 3 & 13 & 95 & 41 & 21 & 33 & 137 & 0.281 & 0.326 \\
\hline \multicolumn{12}{|l|}{ (k) Type of publication media } \\
\hline Academic books & 1 & 1 & 0 & 0 & 3 & 0 & 1 & 2 & 4 & & \\
\hline Book chapters & 1 & 1 & 0 & 1 & 4 & 2 & 2 & 0 & 6 & & \\
\hline Journal articles & 23 & 20 & 3 & 12 & 88 & 39 & 18 & 31 & 123 & & \\
\hline Unpublished working papers & 4 & 4 & 0 & 0 & 0 & 0 & 0 & 0 & 4 & $16.161^{* *}$ & $24.144^{*}$ \\
\hline Total & 29 & 26 & 3 & 13 & 95 & 41 & 21 & 33 & 137 & 0.243 & 0.242 \\
\hline \multicolumn{12}{|l|}{ (1) Specialized fields of publication media } \\
\hline Economics & 22 & 20 & 2 & 12 & 74 & 33 & 17 & 24 & 108 & & \\
\hline Business & 1 & 1 & 0 & 0 & 4 & 0 & 0 & 4 & 5 & & \\
\hline Sociology & 3 & 3 & 0 & 0 & 5 & 1 & 1 & 3 & 8 & & \\
\hline Politics & 2 & 1 & 1 & 0 & 2 & 2 & 0 & 0 & 4 & & \\
\hline International relations & 1 & 1 & 0 & 1 & 4 & 2 & 0 & 2 & 6 & & \\
\hline Regional study & 0 & 0 & 0 & 0 & 6 & 3 & 3 & 0 & 6 & 7.932 & $36.224^{*}$ \\
\hline Total & 29 & 26 & 3 & 13 & 95 & 41 & 21 & 33 & 137 & 0.170 & 0.230 \\
\hline \multicolumn{12}{|l|}{ (m) Publication year } \\
\hline 1989-1993 & 5 & 3 & 2 & 3 & 10 & 6 & 3 & 1 & 18 & & \\
\hline 1994-1998 & 8 & 7 & 1 & 4 & 16 & 6 & 3 & 7 & 28 & & \\
\hline 1999-2003 & 6 & 6 & 0 & 2 & 27 & 13 & 8 & 6 & 35 & & \\
\hline 2004-2008 & 3 & 3 & 0 & 2 & 24 & 10 & 4 & 10 & 29 & & \\
\hline 2009-2014 & 7 & 7 & 0 & 2 & 18 & 6 & 3 & 9 & 27 & 7.951 & 23.452 \\
\hline Total & 29 & 26 & 3 & 13 & 95 & 41 & 21 & 33 & 137 & 0.170 & 0.207 \\
\hline
\end{tabular}




\section{Radicalism}

$\begin{array}{ccc}\text { Total of } & \text { Universal } & \text { Conditional } \\ \text { radicalism } & \text { radicalism } & \text { radicalism }\end{array}$

(1)
Gradualism

Neutralism

(2)

$\begin{array}{cc} & \text { Gradualis } \\ \text { Total of } & \text { Slow-paced } \quad \text { E }\end{array}$

Total of Slow-paced Eclecti

(3) (3a)
Eclectic

(3b)

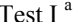

Test II ${ }^{\mathrm{b}}$

Upper: Chi-square $\frac{\text { Upper: Chi-square }}{2}$

test of

test of

Total

independence

independence

Lower: Cramér's Lower: Cramér's

coefficient of coefficient of association $^{\mathrm{c}}$

\section{(n) Quality level}

Grades 1-2

Grades $3-5$

Grades 6-8

Grades 9-10

Totat

Columns (1), (2), and (3) are subjects of the test.

${ }^{6}$ Columns (1a), (1b), (2), (3a), (3b), and (3c) are subjects of the test

***, **, and * denote statistical significance at the $1 \%$ level, $5 \%$ level, and $10 \%$ level, respectively.

Involvement of world-famous economists denotes literature that includes at least one of the following researchers among the authors (Each author's affiliated institution and position that we could confirm while writing this article are indicated in parentheses): Anders Åslund (Senior Fellow, Peterson Institute), Kenneth J. Arrow (Emeritus Professor, Stanford University), Jagdish Bhagwati (Professor, Columbia University), Olivier Blanchard (Professor, Massachusetts Institute of Technology; Economic Counsellor, IMF), Martha de Melo (Former Chief Economist, World Bank), Mathian Dewatripont (Extraordinary Professor, Université libre de Bruxelles; Director, National Bank of Belgium), Stanley Fischer (Vice-Chairman, US Federal Reserve System), Alan Gelb (Senior Fellow, Center for Global Development), Marie Lavigne (Senior Fellow, Institute of Mathematical Sciences and Applied Economics), John McMillan (Professor, Stanford University), Peter Murrell (Mancur Olson Professor, University of Maryland), Douglass C. North (Spencer T. Olin Professor, Washington University; Bartlett Burnap Senior Fellow, Hoover Institution, Stanford University), Vladimir Popov (Adjunct Research Professor, Carleton University at Ottawa; Inter-regional Advisor, United Nations), Gérard Roland (E. Morris Cox Professor, University of California, Berkeley), Jeffrey Sachs (Director of the Earth Institute, Columbia University), Andrei Shleifer (Professor, Harvard University), Joseph E. Stiglitz (Professor, Columbia University).

For more details on the evaluation method, see Appendix B. 
Table 2. Type and descriptive statistics of variables used in regression estimation and correlation coefficients between independent variables and two dependent variables

\begin{tabular}{|c|c|c|c|c|c|c|c|c|c|}
\hline \multirow{2}{*}{ Variable group } & \multirow{2}{*}{ Variable name } & \multirow{2}{*}{$\begin{array}{c}\text { Variable } \\
\text { type }^{\mathrm{a}}\end{array}$} & \multicolumn{5}{|c|}{ Descriptive statistics } & \multirow{2}{*}{$\begin{array}{l}\text { Correlation } \\
\text { coefficient with } \\
\text { the degree of the } \\
\text { radicalism stance } \\
\text { b }\end{array}$} & \multirow{2}{*}{$\begin{array}{l}\text { Correlation } \\
\text { coefficient with } \\
\text { the degree to } \\
\text { which policy } \\
\text { sequence is } \\
\text { stressed }^{\mathrm{b}}\end{array}$} \\
\hline & & & Mean & S.D. & Median & Max & Min & & \\
\hline \multirow{3}{*}{ Debate attitude } & Dependent variables & & & & & & & & \\
\hline & Degree of the radicalism stance ${ }^{c}$ & $\mathrm{O}$ & 0.708 & 1.183 & 0 & 3 & 0 & - & - \\
\hline & Degree to which policy sequence is stressed ${ }^{\mathrm{d}}$ & $\mathrm{O}$ & 0.916 & 0.883 & 1 & 2 & 0 & - & - \\
\hline \multirow{13}{*}{$\begin{array}{l}\text { Authorship } \\
\text { attributes }\end{array}$} & Proportion of affiliated institutions & & & & & & & & \\
\hline & Think tanks & $\mathrm{C}$ & 0.077 & 0.265 & 0 & 1 & 0 & $0.237^{* * *}$ & -0.099 \\
\hline & IMF or World Bank & $\mathrm{C}$ & 0.040 & 0.188 & 0 & 1 & 0 & $0.309^{* * *}$ & 0.010 \\
\hline & Other international institutions & $\mathrm{C}$ & 0.040 & 0.188 & 0 & 1 & 0 & -0.013 & $0.259^{* *}$ \\
\hline & Others & $\mathrm{C}$ & 0.013 & 0.100 & 0 & 1 & 0 & 0.125 & -0.108 \\
\hline & Proportion of location of affiliated institutions & & & & & & & & \\
\hline & North America or Western Europe & $\mathrm{C}$ & 0.756 & 0.421 & 1 & 1 & 0 & -0.009 & -0.167 \\
\hline & CEE & $\mathrm{C}$ & 0.094 & 0.287 & 0 & 1 & 0 & $0.158^{*}$ & 0.156 \\
\hline & FSU & $\mathrm{C}$ & 0.056 & 0.227 & 0 & 1 & 0 & 0.003 & $0.201^{*}$ \\
\hline & Other authorship attributes & & & & & & & & \\
\hline & Median value of authors' first publication year ${ }^{\mathrm{e}}$ & $\mathrm{C}$ & 1987.940 & 11.201 & 1990 & 2008.5 & 1951 & -0.083 & -0.023 \\
\hline & Proportion of female researchers & $\mathrm{C}$ & 0.082 & 0.245 & 0 & 1 & 0 & 0.088 & -0.099 \\
\hline & Involvement of world-famous economists ${ }^{\mathrm{f}}$ & $\mathrm{D}$ & 0.195 & 0.397 & 0 & 1 & 0 & 0.064 & -0.015 \\
\hline \multirow{19}{*}{$\begin{array}{l}\text { Research } \\
\text { content } \\
\text { attributes }\end{array}$} & Focus on particular regions or countries & & & & & & & & \\
\hline & FSU bloc & $\mathrm{D}$ & 0.020 & 0.141 & 0 & 1 & 0 & -0.073 & -0.069 \\
\hline & China & $\mathrm{D}$ & 0.054 & 0.226 & 0 & 1 & 0 & -0.055 & 0.020 \\
\hline & Cuba & $\mathrm{D}$ & 0.007 & 0.082 & 0 & 1 & 0 & -0.052 & 0.127 \\
\hline & Czech Republic or Czechoslovakia & $\mathrm{D}$ & 0.020 & 0.141 & 0 & 1 & 0 & -0.073 & -0.069 \\
\hline & Hungary & $\mathrm{D}$ & 0.007 & 0.082 & 0 & 1 & 0 & -0.052 & -0.108 \\
\hline & Poland & $\mathrm{D}$ & 0.013 & 0.115 & 0 & 1 & 0 & $0.237^{* * *}$ & - \\
\hline & Certain countries in Southeastern Europe & $\mathrm{D}$ & 0.047 & 0.212 & 0 & 1 & 0 & -0.111 & $0.222^{* *}$ \\
\hline & Russia & $\mathrm{D}$ & 0.094 & 0.293 & 0 & 1 & 0 & 0.099 & -0.111 \\
\hline & Uzbekistan & $\mathrm{D}$ & 0.027 & 0.162 & 0 & 1 & 0 & -0.090 & $-0.188^{*}$ \\
\hline & Focus on particular policy areas & & & & & & & & \\
\hline & Economic liberalization & $\mathrm{D}$ & 0.013 & 0.115 & 0 & 1 & 0 & $0.185^{* *}$ & - \\
\hline & Macroeconomic stabilization & $\mathrm{D}$ & 0.040 & 0.197 & 0 & 1 & 0 & -0.038 & 0.023 \\
\hline & Privatization & $\mathrm{D}$ & 0.040 & 0.197 & 0 & 1 & 0 & -0.084 & 0.020 \\
\hline & Enterprise reform and corporate restructuring & $\mathrm{D}$ & 0.034 & 0.181 & 0 & 1 & 0 & -0.117 & 0.130 \\
\hline & Other research content attributes & & & & & & & & \\
\hline & Outcomes from academic projects & $\mathrm{D}$ & 0.114 & 0.319 & 0 & 1 & 0 & -0.112 & -0.040 \\
\hline & Employment of mathematical economic model & $\mathrm{D}$ & 0.154 & 0.363 & 0 & 1 & 0 & -0.038 & $-0.213^{* *}$ \\
\hline & Intensity of empirical examination ${ }^{\mathrm{g}}$ & $\mathrm{O}$ & 0.463 & 0.683 & 0 & 2 & 0 & $0.325^{* * *}$ & -0.050 \\
\hline \multirow{13}{*}{$\begin{array}{l}\text { Publication } \\
\text { media attributes }\end{array}$} & Type of publication media & & & & & & & & \\
\hline & Academic book & $\mathrm{D}$ & 0.027 & 0.162 & 0 & 1 & 0 & 0.006 & 0.154 \\
\hline & Book chapter & $\mathrm{D}$ & 0.040 & 0.197 & 0 & 1 & 0 & -0.008 & -0.099 \\
\hline & Unpublished working paper & $\mathrm{D}$ & 0.027 & 0.162 & 0 & 1 & 0 & $0.337^{* * *}$ & - \\
\hline & Specialized fields of publication media & & & & & & & & \\
\hline & Business & $\mathrm{D}$ & 0.040 & 0.197 & 0 & 1 & 0 & -0.018 & $0.259^{* *}$ \\
\hline & Sociology & $\mathrm{D}$ & 0.054 & 0.226 & 0 & 1 & 0 & 0.088 & 0.130 \\
\hline & Politics & $\mathrm{D}$ & 0.027 & 0.162 & 0 & 1 & 0 & 0.080 & -0.153 \\
\hline & International relations & $\mathrm{D}$ & 0.040 & 0.197 & 0 & 1 & 0 & -0.008 & 0.020 \\
\hline & Regional study & $\mathrm{D}$ & 0.040 & 0.197 & 0 & 1 & 0 & -0.129 & -0.123 \\
\hline & Other publication media attributes & & & & & & & & \\
\hline & Publication year & $\mathrm{C}$ & 2001.738 & 6.499 & 2002 & 2014 & 1989 & -0.071 & 0.147 \\
\hline & Quality level ${ }^{\mathrm{h}}$ & $\mathrm{O}$ & 4.020 & 3.332 & 4 & 9 & 0 & 0.097 & $-0.200^{*}$ \\
\hline
\end{tabular}

${ }^{\mathrm{a}} \mathrm{C}$ : Continuous variable; D: Dummy variable; O: Ordered variable

$\mathrm{b} * * *, * *$, and $*$ denote statistical significance at the $1 \%$ level, $5 \%$ level, and $10 \%$ level, respectively.

${ }^{\mathrm{c}}$ Ordered variable that gives a value of 0 to gradualism, 1 to neutralism, 2 to conditional radicalism, and 3 to universal radicalism

${ }^{\mathrm{d}}$ Ordered variable that gives a value of 0 to slow-paced gradualism, 1 to eclectic gradualism, and 2 to step-by-step gradualism

${ }^{\mathrm{e}}$ Based on the first publication year of each author registered in the ProQuest database

${ }^{\mathrm{f}}$ Dummy variable that gives a value of 1 to literature that includes at least one of the following researchers among the authors (Each author's affiliated institution and position that we could confirm while writing this article are indicated in parentheses): Anders Åslund (Senior Fellow, Peterson Institute), Kenneth J. Arrow (Emeritus Professor, Stanford University), Jagdish Bhagwati (Professor, Columbia University), Olivier Blanchard (Professor, Massachusetts Institute of Technology; Economic Counsellor, IMF), Martha de Melo (Former Chief Economist, World Bank), Mathian Dewatripont (Extraordinary Professor, Université libre de Bruxelles; Director, National Bank of Belgium), Stanley Fischer (Vice-Chairman, US Federal Reserve System), Alan Gelb (Senior Fellow, Center for Global Development), Marie Lavigne (Senior Fellow, Institute of Mathematical Sciences and Applied Economics), John McMillan (Professor, Stanford University), Peter Murrell (Mancur Olson Professor, University of Maryland), Douglass C. North (Spencer T. Olin Professor, Washington University; Bartlett Burnap Senior Fellow, Hoover Institution, Stanford University), Vladimir Popov (Adjunct Research Professor, Carleton University at Ottawa; Inter-regional Advisor, United Nations), Gérard Roland (E. Morris Cox Professor, University of California, Berkeley), Jeffrey Sachs (Director of the Earth Institute, Columbia University), Andrei Shleifer (Professor, Harvard University), Joseph E. Stiglitz (Professor, Columbia University).

${ }^{\mathrm{g}}$ Ordered variable that gives a value of 0 to studies without quantitative analysis, 1 to studies using quantitative data, and 2 to econometric studies.

${ }^{\mathrm{h}}$ For more details on the evaluation method, see Appendix B. 
Table 3. Estimation results of ordered probit model on the relationship between the debate attitudes and the literature attributes ${ }^{\mathrm{a}}$

\begin{tabular}{|c|c|c|c|c|c|c|}
\hline Model & \multicolumn{3}{|c|}{$[1]$} & \multicolumn{3}{|c|}{$[2]$} \\
\hline Dependent variable & \multicolumn{3}{|c|}{ Degree of the radicalism stance } & \multicolumn{3}{|c|}{ Degree to which policy sequence is stressed } \\
\hline Sample literature & \multicolumn{3}{|c|}{ Basic collection } & \multicolumn{3}{|c|}{ Gradualism literature } \\
\hline Independent variables (Default category) & Coefficient & S.D. ${ }^{b}$ & z-value & Coefficient & S.D. ${ }^{b}$ & z-value \\
\hline \multicolumn{7}{|c|}{ Proportion of affiliated institutions (Universities or academic research institutions) } \\
\hline Think tanks & 1.480 & 0.637 & $2.33^{* *}$ & -0.916 & 0.652 & -1.41 \\
\hline IMF or World Bank & 5.448 & 1.652 & $3.30^{* * *}$ & 5.898 & 0.978 & $6.03^{* * *}$ \\
\hline Other international institutions & 0.380 & 0.738 & 0.51 & 6.352 & 0.703 & $9.04^{* * *}$ \\
\hline Others & 0.004 & 0.821 & 0.00 & -11.198 & 1.033 & $-10.84^{* * *}$ \\
\hline \multicolumn{7}{|c|}{ Proportion of location of affiliated institutions (Asia and Oceania) } \\
\hline North America or Western Europe & 2.413 & 0.770 & $3.13^{* * * *}$ & -0.222 & 0.480 & -0.46 \\
\hline CEE & 3.282 & 0.870 & $3.77^{* * * *}$ & 1.242 & 0.796 & 1.56 \\
\hline FSU & 2.633 & 1.057 & $2.49^{* *}$ & 1.217 & 0.788 & 1.54 \\
\hline \multicolumn{7}{|l|}{ Other authorship attributes } \\
\hline Median value of authors' first publication year & -0.035 & 0.016 & $-2.20^{* *}$ & -0.005 & 0.017 & -0.29 \\
\hline Proportion of female researchers & 0.596 & 0.542 & 1.10 & -2.128 & 1.360 & -1.56 \\
\hline Involvement of world-famous economists & -1.514 & 0.514 & $-2.95^{* * *}$ & 0.844 & 0.709 & 1.19 \\
\hline \multicolumn{7}{|c|}{ Focus on particular regions or countries (Without any particular subject regions or countries) } \\
\hline FSU bloc & -10.187 & 1.610 & $-6.33^{* * *}$ & -5.366 & 0.618 & $-8.68^{* * *}$ \\
\hline China & 2.135 & 0.744 & $2.87^{* * *}$ & 0.333 & 0.569 & 0.59 \\
\hline Cuba & -6.845 & 1.022 & $-6.70^{* * *}$ & 8.373 & 1.437 & $5.83^{* * *}$ \\
\hline Czech Republic or Czechoslovakia & -2.843 & 0.877 & $-3.24^{* * *}$ & -0.111 & 0.911 & -0.12 \\
\hline Hungary & -6.625 & 0.688 & $-9.63^{* * *}$ & -5.526 & 0.875 & $-6.32^{* * *}$ \\
\hline Poland & 10.477 & 0.981 & $10.68^{* * *}$ & - & - & - \\
\hline Certain countries in Southeastern Europe & -0.798 & 0.696 & -1.15 & 2.651 & 1.124 & $2.36^{* *}$ \\
\hline Russia & -0.014 & 0.613 & -0.02 & -0.736 & 0.830 & -0.89 \\
\hline Uzbekistan & -5.822 & 0.492 & $-11.84^{* * *}$ & -5.838 & 1.542 & $-3.79^{* * *}$ \\
\hline \multicolumn{7}{|l|}{ Focus on particular policy areas (Policies in general) } \\
\hline Economic liberalization & 2.075 & 0.820 & $2.53^{* *}$ & - & - & - \\
\hline Macroeconomic stabilization & -5.770 & 0.694 & $-8.32^{* * *}$ & 0.376 & 0.610 & 0.62 \\
\hline Privatization & -0.559 & 0.643 & -0.87 & -2.375 & 1.150 & $-2.07^{* *}$ \\
\hline Enterprise reform and corporate restructuring & -7.056 & 0.788 & $-8.95^{* * *}$ & 0.238 & 0.742 & 0.32 \\
\hline \multicolumn{7}{|l|}{ Other research content attributes } \\
\hline Outcomes from academic projects & -0.359 & 0.518 & -0.69 & -0.291 & 0.539 & -0.54 \\
\hline Employment of mathematical economic model & 0.315 & 0.409 & 0.77 & -0.207 & 0.444 & -0.47 \\
\hline Intensity of empirical examination & 1.044 & 0.303 & $3.44^{* * * *}$ & -0.388 & 0.324 & -1.20 \\
\hline \multicolumn{7}{|l|}{ Type of publication media (Journal article) } \\
\hline Academic book & 1.993 & 1.024 & $1.95^{*}$ & 1.334 & 0.695 & $1.92^{*}$ \\
\hline Book chapter & 1.678 & 0.675 & $2.49^{* *}$ & -0.766 & 0.911 & -0.84 \\
\hline Unpublished working paper & 12.082 & 0.998 & $12.11^{* * *}$ & - & - & - \\
\hline \multicolumn{7}{|l|}{ Specialized fields of publication media (Economics) } \\
\hline Business & -3.446 & 0.851 & $-4.05^{* * *}$ & 7.663 & 1.634 & $4.69^{* * *}$ \\
\hline Sociology & 2.326 & 0.864 & $2.69^{* * *}$ & 0.558 & 0.878 & 0.64 \\
\hline Politics & 2.820 & 0.847 & $3.33^{* * *}$ & -6.269 & 0.558 & $-11.23^{* * *}$ \\
\hline International relations & 0.337 & 1.044 & 0.32 & 2.531 & 1.020 & $2.48^{* *}$ \\
\hline Regional study & -5.801 & 0.702 & $-8.27^{* * *}$ & 0.220 & 0.563 & 0.39 \\
\hline \multicolumn{7}{|l|}{ Other publication media attributes } \\
\hline Publication year & 0.037 & 0.038 & 0.98 & 0.043 & 0.042 & 1.02 \\
\hline Quality level & 0.265 & 0.073 & $3.62^{* * *}$ & -0.034 & 0.074 & -0.45 \\
\hline$N$ & & 137 & & & 95 & \\
\hline Log pseudolikelihood & & -67.145 & & & -67.771 & \\
\hline Pseudo $R^{2}$ & & 0.441 & & & 0.329 & \\
\hline Akaike's information criterion (AIC) & & 212.290 & & & 203.543 & \\
\hline Bayesian information criterion (BIC) & & 326.170 & & & 290.375 & \\
\hline Wald test $\left(\chi^{2}\right)^{\mathrm{c}}$ & 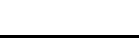 & 3256.840 & & & 3520.210 & \\
\hline
\end{tabular}


Table 4. Estimation results of multinominal logit model on the relationship between the debate attitudes and the literature attributes in the gradualism literature ${ }^{\text {a }}$

\begin{tabular}{|c|c|c|c|c|c|c|}
\hline \multirow{2}{*}{$\begin{array}{l}\text { Dependent variables (Base category: Slow-paced gradualism) } \\
\text { Independent variables (Default category) }\end{array}$} & \multicolumn{3}{|c|}{ Eclectic gradualism } & \multicolumn{3}{|c|}{ Step-by-step gradualism } \\
\hline & Coefficient & S.D. ${ }^{\mathrm{b}}$ & z-value & Coefficient & S.D. ${ }^{\mathrm{b}}$ & z-value \\
\hline \multicolumn{7}{|c|}{ Proportion of affiliated institutions (Universities or academic research institutions) } \\
\hline Think tanks & -20.066 & 1.549 & $-12.96^{* * *}$ & -15.521 & 1.925 & $-8.06^{* * *}$ \\
\hline IMF or World Bank & 40.498 & 2.970 & $13.64^{* * *}$ & 39.107 & 2.927 & $13.36^{* * *}$ \\
\hline Other international institutions & 0.818 & 1.262 & 0.65 & 18.760 & 1.759 & $10.66^{* * *}$ \\
\hline Others & -41.185 & 2.806 & $-14.68^{* * *}$ & -38.354 & 3.257 & $-11.77^{* * *}$ \\
\hline \multicolumn{7}{|l|}{ Proportion of locations of affiliated institutions (Asia and Oceania) } \\
\hline North America or Western Europe & -1.164 & 1.372 & -0.85 & -0.078 & 0.931 & -0.08 \\
\hline CEE & -18.032 & 2.125 & $-8.49^{* * *}$ & 20.074 & 1.146 & $17.52^{* * *}$ \\
\hline FSU & -18.137 & 2.051 & $-8.84^{* * *}$ & 22.985 & 2.250 & $10.22^{* * *}$ \\
\hline \multicolumn{7}{|l|}{ Other authorship attributes } \\
\hline Median value of authors' first publication year & -0.056 & 0.040 & -1.40 & -0.011 & 0.050 & -0.22 \\
\hline Proportion of female researchers & 0.523 & 1.926 & 0.27 & -123.495 & 3.983 & $-31.00^{* * *}$ \\
\hline Involvement of world-famous economists & 2.006 & 1.131 & $1.77^{*}$ & 0.219 & 1.733 & 0.13 \\
\hline \multicolumn{7}{|c|}{ Focus on particular regions or countries (Without any particular subject regions or countries) } \\
\hline FSU bloc & -18.437 & 1.926 & $-9.57^{* * *}$ & -20.543 & 1.757 & $-11.69^{* * *}$ \\
\hline China & 1.983 & 1.297 & 1.53 & 1.805 & 1.435 & 1.26 \\
\hline Cuba & 20.423 & 2.500 & $8.17^{* * *}$ & 85.330 & 3.771 & $22.63^{* * *}$ \\
\hline Czech Republic or Czechoslovakia & 1.943 & 2.439 & 0.80 & -19.057 & 1.964 & $-9.70^{* * *}$ \\
\hline Hungary & -10.192 & 1.798 & $-5.67^{* * *}$ & -30.799 & 2.639 & $-11.67^{* * *}$ \\
\hline Poland & - & - & - & - & - & - \\
\hline Certain countries in Southeastern Europe & -18.563 & 2.140 & $-8.67^{* * *}$ & 106.551 & 4.148 & $25.69^{* * * *}$ \\
\hline Russia & 0.897 & 1.510 & 0.59 & -41.326 & 2.100 & $-19.68^{* * *}$ \\
\hline Uzbekistan & -21.437 & 2.036 & $-10.53^{* * *}$ & -18.223 & 1.718 & $-10.61^{* * *}$ \\
\hline \multicolumn{7}{|l|}{ Focus on particular policy areas (Policies in general) } \\
\hline Economic liberalization & - & - & - & - & - & - \\
\hline Macroeconomic stabilization & 0.691 & 2.266 & 0.31 & -17.227 & 1.651 & $-10.43^{* * *}$ \\
\hline Privatization & -20.636 & 1.289 & $-16.00^{* * *}$ & -89.377 & 3.608 & $-24.77^{* * *}$ \\
\hline Enterprise reform and corporate restructuring & 0.545 & 1.896 & 0.29 & -16.691 & 2.465 & $-6.77^{* * *}$ \\
\hline \multicolumn{7}{|l|}{ Other research content attributes } \\
\hline Outcomes from academic projects & -0.540 & 1.050 & -0.51 & 0.132 & 1.595 & 0.08 \\
\hline Employment of mathematical economic model & 0.619 & 0.955 & 0.65 & -1.210 & 1.221 & -0.99 \\
\hline Intensity of empirical examination & -0.315 & 0.609 & -0.52 & -0.053 & 1.230 & -0.04 \\
\hline \multicolumn{7}{|l|}{ Type of publication media (Journal article) } \\
\hline Academic book & 20.671 & 2.736 & $7.55^{* * *}$ & 20.477 & 2.591 & $7.90^{* * *}$ \\
\hline Book chapter & -0.029 & 1.864 & -0.02 & -18.661 & 2.257 & $-8.27^{* * *}$ \\
\hline Unpublished working paper & - & - & - & - & - & - \\
\hline \multicolumn{7}{|l|}{ Specialized fields of publication media (Economics) } \\
\hline Business & 0.099 & 2.749 & 0.04 & 159.579 & 6.200 & $25.74^{* * *}$ \\
\hline Sociology & 0.505 & 1.851 & 0.27 & 25.785 & 2.353 & $10.96^{* * *}$ \\
\hline Politics & -22.084 & 1.840 & $-12.00^{* * *}$ & -19.072 & 1.583 & $-12.04^{* * *}$ \\
\hline International relations & 2.898 & 1.617 & $1.79^{*}$ & 73.404 & 3.205 & $22.90^{* * *}$ \\
\hline Regional study & 0.913 & 1.161 & 0.79 & -18.231 & 1.919 & $-9.50^{* * *}$ \\
\hline \multicolumn{7}{|l|}{ Other publication media attributes } \\
\hline Publication year & 0.124 & 0.095 & 1.31 & -0.018 & 0.113 & -0.15 \\
\hline Quality level & 0.052 & 0.163 & 0.32 & 0.033 & 0.200 & 0.16 \\
\hline Const. & -138.221 & 171.456 & -0.81 & 55.949 & 215.449 & 0.26 \\
\hline$N$ & \multicolumn{6}{|c|}{95} \\
\hline Log pseudolikelihood & \multicolumn{6}{|c|}{-48.290} \\
\hline Pseudo $R^{2}$ & \multicolumn{6}{|c|}{0.522} \\
\hline Akaike's information criterion (AIC) & \multicolumn{6}{|c|}{218.580} \\
\hline Bayesian information criterion (BIC) & \multicolumn{6}{|c|}{374.367} \\
\hline Wald test $\left(\chi^{2}\right)^{\mathrm{c}}$ & \multicolumn{3}{|c|}{$5506.84^{* * *}$} & \multicolumn{3}{|c|}{$9579.72^{* * *}$} \\
\hline
\end{tabular}

